\title{
International Macroeconomics With Imperfect Financial Markets
}

\author{
Matteo Maggiori*
}

February 2020

\begin{abstract}
A review of recent advances in open economy analysis under segmented international financial markets. A set of modeling tools that have been used to understand financial crises, the ensuing policy response (e.g., Quantitative Easing and FX intervention), deviations from arbitrage (CIP deviations), and more generally the impact of capital flows on exchange rates. This modeling approach has also sheds a different light on classic topics such as the exchange rate disconnect, international risk sharing, UIP failures, and the carry trade.
\end{abstract}

Keywords: Financial frictions, Market Segmentation, Risk Bearing Capacity, Global Financial Institutions, FX Intervention, CIP, Exchange Rate Disconnect, International Monetary System.

JEL Codes: F31, F32, F33, F36, F38, F41, F42, F65, G11, G15, G20, H12.

*Stanford University Graduate School of Business, NBER, and CEPR; maggiori@stanford.edu. Chapter in preparation for the Handbook of International Economics. I thank Jesse Schreger and Wenxin Du for useful comments and the volume editors Gita Gopinath, Elhanan Helpman, and Kenneth Rogoff. 
The last fifteen years have been dominated by three large crises: the global financial crisis of 2008-09, the European sovereign debt crisis of 2011-12, and the ongoing Covid19 pandemic in 2020. In all these episodes, capital and asset prices moved abruptly, often with adverse consequences for the global economy. Traditional monetary policy quickly ran out of power due to the zero lower bound (ZLB) constraint, and policymakers resorted to alternate policies, such as quantitative easing, intervention in foreign exchange markets, and capital controls. Times of global stress also highlighted the central role of the U.S. dollar and the liquidity of U.S. markets. Understanding and improving the economics of these episodes requires a conceptual framework in which imperfections in financial markets are at the center stage. This chapter reviews some of the scientific advances made in the last few years in attempting to meet this challenge.

The field of international macroeconomics and finance has progressed both empirically and theoretically by focusing on the question of who owns which assets around the world. On the theoretical front, this has required not only new models but also, in some cases, going back to older insights that had been largely forgotten, such as the portfolio balance theories in the 1970s. On the empirical front, we have witnessed, starting in 2007, the breakdown of the Covered Interest Parity (CIP) condition, a central condition for the absence of arbitrage. It is rare to witness such a dramatic change in a basic condition of one of the most established financial markets. This prime evidence for currency market segmentation, reviewed extensively in the companion handbook chapter by Du and Schreger (2021), is inconsistent with models of perfect financial markets, including those that generate imperfect substitubability among currencies via risk premia.

This chapter focuses on the recent literature that used financial frictions as a foundation for imperfect substitutability of assets in different currencies. The presence of market segmentation and financial frictions generates a set of specific predictions: CIP deviations, a direct effect of gross portfolio flows on exchange rates, and the effectiveness of foreign exchange intervention. It also casts a different light on classic stylized facts in the field, such as the disconnect of exchange rates from macro fundamentals 
and the carry trade.

In models with imperfect financial intermediation, the exchange rate is pinned down by imbalances in the demand and supply of assets in different currencies and, crucially, by the limited risk-bearing capacity of financiers that absorb these imbalances. The demand for the assets, a gross capital flow, or the financiers' risk-bearing capacity might only have a distant relation with macro fundamentals, thus contributing to generating the disconnect. By placing global portfolios at the center stage, this line of research stresses the importance of better data to understand these financial forces and their impact on the real economy, an ongoing effort in the field.

On the policy front, the financial frictions view offers a different take on exchange rates compared to their traditional role as shock absorbers. Exchange rates are distorted by financial forces and can be a source of shocks to the real economy rather than a re-equilibrating mechanism. Quantitative easing and FX intervention, the purchase of domestic and foreign currency assets by the central bank, respectively, are ineffective in perfect markets but effective and, if used appropriately, welfare-enhancing policies under imperfect markets. Their ineffectiveness in perfect markets relies on a combination of Modigliani-Miller logic applied to the balance sheet of the central bank and Ricardian equivalence. Under these conditions, if the central bank buys foreign currency assets while selling domestic currency assets, agents in the economy simply take the opposite position since they understand that the central bank is trading on their behalf in an undesired way. Future losses or gains arising from the central bank position are passed through to the agents without distorting their actions.

Limited financial intermediation breaks the Modigliani-Miller component because the intervention is a risk transfer between the central bank and constrained financial intermediaries. The presence of financial constraints, and/or imperfections in the goods market like sticky prices, are at the core not only of the effectiveness of interventions but also provide a deeper rationale for their optimal use. Private decisions in the presence of pecuniary and/or demand externalities are no longer optimal thus generating a role for government intervention even under the strict criterion of constrained Pareto 
optimality. The study of these optimal policies is reviewed extensively in the companion handbook chapter by Bianchi and Lorenzoni (2021).

An intuitive way to visualize the conceptual difference of international macro models with segmented currency markets is illustrated in Figure 1. Let us start with a simple two country model, for concreteness, say the U.S. and Japan. These countries trade in the goods market with each other because they produce heterogeneous goods which they both enjoy consuming (in different proportions). Shocks across states of the world and time also generate motives to trade in financial assets. The more traditional setup is to make these countries also face each other in financial markets with a menu of assets that might be complete or incomplete. The financial intermediation view breaks this structure by introducing global financiers at the core of the model. Both countries trade in a limited set of assets, for concreteness say bonds in dollars and yen, against the financiers. Ultimately, the financiers are owned by the households in each country and receive the profits/losses of intermediation. If the financiers behaved optimally, then they would simply be a veil and the model would be much the same without them. The model, therefore, comes alive when financial frictions limit the ability of the financiers to take on positions. This basic structure is used for most of this chapter to provide a unified view of many issues in positive and normative international macroeconomics as well as review the many different choices that papers have made on each element of the structure.

The intellectual origin of this modeling traces back to the Nurkse (1944) view of capital flows as inducing volatile and destabilizing exchange rate movements. The field has been inspired by the pioneering work of Penti Kouri on the portfolio balance approach to exchange rates. In 1976, two foundational papers in international macroeconomics appeared in print: the portfolio balance paper of Kouri (1976) and the overshooting model of Dornbusch (1976). The Dornbusch framework has had a deep and enduring influence on the field, including on the new open economy macroeconomics literature started by Obstfeld and Rogoff (1995). A number of economists have lamented, instead, 
Figure 1: Basic Structure of a Segmented Currency Market Model

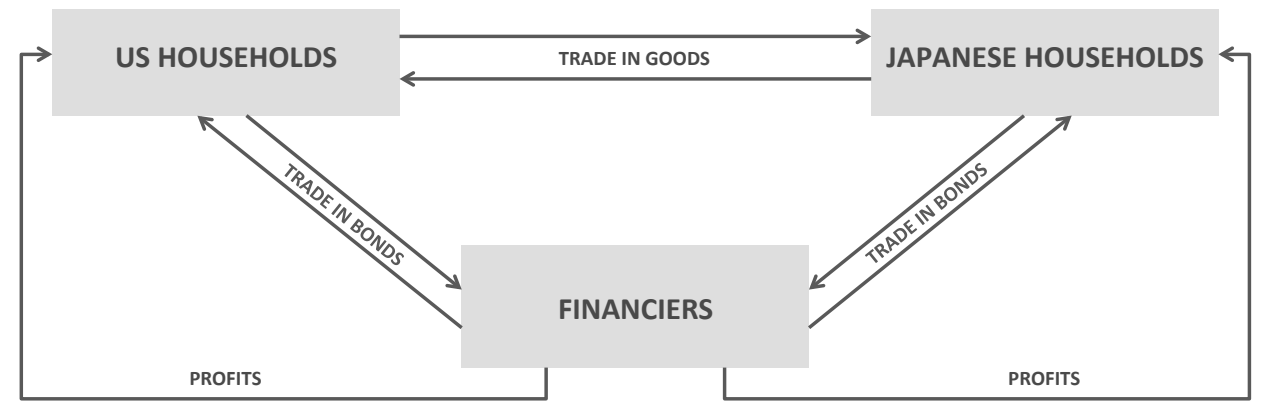

The players and structure of the flows in the goods and financial markets. Reproduced from Gabaix and Maggiori (2015).

that the Penti Kouri approach "had its high watermark and to a large extent a terminus in Branson and Henderson (1985) handbook chapter" (see Obstfeld (2004)) and is "now largely and unjustly forgotten" (see Blanchard et al. (2005)). ${ }^{1}$

At the core of the portfolio balance approach is the idea of imperfect substitutability of assets denominated in different currencies. This contrasts with the traditional macroeconomics approach of imposing, either explicitly or implicitly via solution methods, the uncovered interest parity (UIP) condition of perfect substitutability. ${ }^{2}$ An important literature gave modern theoretical foundations to imperfect substitutability via risk premia in perfect markets (Lucas, 1982; Backus et al., 1992; Backus and Smith, 1993; Dumas, 1992; Verdelhan, 2010; Colacito and Croce, 2011; Hassan, 2013; Farhi and Gabaix, 2016). A smaller literature has analyzed the importance of incomplete markets (for recent examples: Chari et al. (2002); Corsetti et al. (2008); Pavlova and Rigobon (2012)). Lustig and Verdelhan (2019) show that even under incomplete markets, it is difficult to simultaneously account for lack of risk sharing, currency risk premia, and the volatility dynamics of exchange rates compared to fundamentals.

This chapter reviews the recent literature that uses market segmentation and finan-

\footnotetext{
${ }^{1}$ An active early literature also includes: Driskill and McCafferty (1980a); Allen and Kenen (1983); De Grauwe (1982); Henderson and Rogoff (1982); Dornbusch and Fischer (1980); Calvo and Rodriguez (1977); Branson et al. (1979); Tobin and de Macedo (1979); Diebold and Pauly (1988); Driskill and McCafferty (1980b); de Macedo and Lempinen (2013).

${ }^{2}$ Explicitly by modeling risk neutral agents or purely idiosyncratic exchange rate risk; implicitly by solving the model with first order approximations that effectively impose no risk premia.
} 
cial frictions as a foundation for imperfect substitutability. Jeanne and Rose (2002) show how endogenous market segmentation can relax the Mundellian Trilemma: under some conditions, it is possible to reduce exchange rate volatility without sacrificing monetary autonomy. Alvarez, Atkeson and Kehoe (2002, 2009) study monetary operations and their effect on exchange rates in a model in which the markets for bonds and money (domestically) are segmented. Hau and Rey (2006) study a model of segmentation in equity markets with incomplete foreign exchange risk taking that links portfolio flows in equities to exchange rates. Bacchetta and Van Wincoop (2010) study the implications for exchange rates of agents who infrequently rebalance their bond portfolios. $^{3}$

Gabaix and Maggiori (2015) provides a simple general-equilibrium framework of the portfolio-balance determination of exchange rates under segmented currency markets. Theories of market segmentation have proved a fertile ground for understanding the use of FX intervention as a policy tool (Cavallino (2019); Amador, Bianchi, Bocola and Perri (2020); Fanelli and Straub (2020); Davis, Devereux and Yu (2020)) and are being incorporated in new efforts to broaden policy makers' toolbox (Basu, Boz, Gopinath, Roch and Unsal (2020)). Greenwood, Hanson, Stein and Sunderam (2020) and Gourinchas, Ray and Vayanos (2020) study a segmented market model with both long-term and short-term bonds across currencies, thus providing a joint analysis of currency and term premia. Itskhoki and Mukhin (2021) and Itskhoki and Mukhin (2020) show that financial forces are at the core of real exchange rate dynamics and their disconnect from macro fundamentals. A strand of the literature has used market segmentation and convenience yields to understand CIP and its connection with exchange rates (see: Garleanu and Pedersen (2011); Du, Hébert and Huber (2019); Jiang, Krishnamurthy and Lustig (2018); Engel and Wu (2018)).

On the empirical front, a crucial question is the nature and degree of market segmentation. Hau, Massa and Peress (2010), Pandolfi and Williams (2019), and Broner,

\footnotetext{
${ }^{3}$ There is also a literature started by Evans and Lyons (2002) in market micro-structure that focuses on the information content of trades in FX markets.
} 
Martin, Pandolfi and Williams (2020) take a reduced-form identification approach using changes in indexation of bonds and equities to identify the causal effect of portfolio flows on exchange rates. They provide evidence of segmentation broadly consistent with the theoretical models discussed above. There is also an emerging literature that uses structural approaches, coming from industrial organization, to study segmentation and its implication for global asset prices (Koijen and Yogo (2020), Jiang, Richmond and Zhang (2020b), Pellegrino, Spolaore and Wacziarg (2020)). Using a complementary approach this literature also points to an important role for market segmentation.

For most of this Chapter, we focus on financial frictions in a standard two country symmetric setup. The world, however, is hardly symmetric. Some countries and assets play a special role and these asymmetries have been an important element in the large crises of the last 20 years mentioned in the opening motivation to this Chapter. In the concluding section, we briefly review recent advances in theoretical modeling that focused on self-fulfilling financial crises and equilibrium multiplicity to understand the role of safe assets, like US treasuries, and the U.S. in an asymmetric international monetary system (He, Krishnamurthy and Milbradt (2019); Farhi and Maggiori (2018); Gopinath and Stein (2020); Chahrour and Valchev (2018)). Many advanced economies, including the US, have been increasing their debt to GDP ratios rapidly, opening up the concern of a future wave of debt crisis. These models are a useful framework to analyze these potential risks in the international monetary system.

\section{A Simple Theoretical Framework}

To make ideas concrete, we will sketch here a version of the model in Gabaix and Maggiori (2015). Going back to Figure 1, there are two countries, the US and Japan, and two periods $t=0,1$. The setup of households in each country is mostly standard. Households in the US derive utility from the consumption of goods according to:

$$
\theta_{0} \ln C_{0}+\beta \mathbb{E}\left[\theta_{1} \ln C_{1}\right]
$$


where $C$ is a consumption basket defined as:

$$
C_{t} \equiv\left[\left(C_{N T, t}\right)^{\chi_{t}}\left(C_{H, t}\right)^{a_{t}}\left(C_{F, t}\right)^{\iota_{t}}\right]^{\frac{1}{\theta_{t}}},
$$

where $C_{N T, t}$ is the US consumption of its non-tradable goods, $C_{H, t}$ is the US consumption of its domestic tradable goods, and $C_{F, t}$ is the US consumption of Japanese tradable goods. We use the notation $\left\{\chi_{t}, a_{t}, \iota_{t}\right\}$ for non-negative, potentially stochastic, preference parameters and we define $\theta_{t} \equiv \chi_{t}+a_{t}+\iota_{t}$. Pavlova and Rigobon (2007) introduced these preference shocks together with logarithmic preferences to maintain the tractability of log preferences while breaking the Cole and Obstfeld (1991) result on the irrelevance of financial markets. ${ }^{4}$ The non-tradable good is the numéraire in each economy and, consequently, its price equals one in domestic currency $\left(p_{N T}=1\right)$.

To sharpen the focus on financial forces, we start with a frictionless goods market across countries and flexible prices. The law of one price holds in the goods market. Financial markets, instead, are incomplete and each country trades a risk-free domestic currency bond that pays one unit of non-tradable goods in all states of the world.

US households' optimization problem is:

$$
\max _{\left(C_{N T, t}, C_{H, t}, C_{F, t}\right)_{t=0,1}} \theta_{0} \ln C_{0}+\beta \mathbb{E}\left[\theta_{1} \ln C_{1}\right],
$$

subject to (2),

and $\sum_{t=0}^{1} R^{-t}\left(Y_{N T, t}+p_{H, t} Y_{H, t}\right)=\sum_{t=0}^{1} R^{-t}\left(C_{N T, t}+p_{H, t} C_{H, t}+p_{F, t} C_{F, t}\right)$.

The static utility maximization problem takes the form:

$\max _{C_{N T, t}, C_{H, t}, C_{F, t}} \chi_{t} \ln C_{N T, t}+a_{t} \ln C_{H, t}+\iota_{t} \ln C_{F, t}+\lambda_{t}\left(C E_{t}-C_{N T, t}-p_{H, t} C_{H, t}-p_{F, t} C_{F, t}\right)$,

where $C E_{t}$ is consumption expenditure on the basket, which is taken as exogenous in this static optimization problem and later endogenized in the dynamic optimization

\footnotetext{
${ }^{4}$ Similar preferences are also used in Pavlova and Rigobon (2008, 2010).
} 
problem, $\lambda_{t}$ is the associated Lagrange multiplier, $p_{H, t}$ is the Dollar price in the US of US tradables, and $p_{F, t}$ is the Dollar price in the US of Japanese tradables. First-order conditions imply: $\frac{\chi_{t}}{C_{N T, t}}=\lambda_{t}$, and $\frac{\iota t}{C_{F, t}}=\lambda_{t} p_{F, t}$. Non-tradable goods are produced by an endowment process that for simplicity follows $Y_{N T, t}=\chi_{t}$, unless otherwise stated. This simplifying assumption, combined with the market clearing condition for non-tradables $Y_{N T, t}=C_{N T, t}$, implies that in equilibrium $\lambda_{t}=1$ in all states. The assumption essentially removes marginal utility variation across states, thus sharpening, as we will see below, the focus on imperfect substitutability between currencies coming from financial frictions.

With this assumption in hand, the Dollar value of US imports is $p_{F, t} C_{F, t}=\iota_{t}$. Japanese households derive utility from consumption according to: $\theta_{0}^{*} \ln C_{0}^{*}+\beta^{*} \mathbb{E}\left[\theta_{1}^{*} \ln C_{1}^{*}\right]$, where starred variables denote Japanese quantities and prices. By analogy with the US case, the Japanese consumption basket is: $C_{t}^{*} \equiv\left[\left(C_{N T, t}^{*}\right)^{\chi_{t}^{*}}\left(C_{H, t}^{*}\right)^{\xi_{t}}\left(C_{F, t}^{*}\right)^{a_{t}^{*}}\right]^{\frac{1}{\theta_{t}^{*}}}$, where $\theta_{t}^{*} \equiv \chi_{t}^{*}+a_{t}^{*}+\xi_{t}$. The Japanese static utility maximization problem together with the symmetric assumption $Y_{N T, t}^{*}=\chi_{t}^{*}$, leads to a Yen value of US exports to Japan, $p_{H, t}^{*} C_{H, t}^{*}=\xi_{t}$. US net exports, expressed in dollars, are given by: $N X_{t}=e_{t} p_{H, t}^{*} C_{H, t}^{*}-p_{F, t} C_{F, t}=\xi_{t} e_{t}-\iota_{t}$. The exchange rate $e_{t}$ is defined as the quantity of dollars bought by 1 yen, i.e. the strength of the Yen. Consequently, an increase in $e$ represents a Dollar depreciation. ${ }^{5}$

The Exchange Rate in Financial Autarky. Under financial autarky, i.e. if trade in the goods markets has to be balanced period by period $\left(N X_{t}=0\right)$, the equilibrium exchange rate is: $e_{t}=\frac{\iota t}{\xi_{t}}$. In financial autarky, the Dollar depreciates $(\uparrow e)$ whenever US demand for Japanese goods increases $(\uparrow \iota)$ or whenever Japanese demand for US goods falls $(\downarrow \xi)$. This has to occur because there is no mechanism, in this case, to absorb the excess demand/supply of dollars versus yen that a non-zero trade

\footnotetext{
${ }^{5}$ In this simple real model, the exchange rate is related to the relative price of non-tradable goods. Gabaix and Maggiori (2015) provides a detailed discussion of different exchange rate concepts in this economy including the nominal and CPI-based real exchange rate. The analogy with the nominal is perhaps the most straightforward by thinking of non-tradable goods as money in the utility function.
} 
balance would generate. The equilibrium exchange rate is myopic in the sense that it only reflects current fundamentals.

The optimization problem (3) for the intertemporal consumption-saving decision leads to a standard optimality condition (Euler equation):

$$
1=\mathbb{E}\left[\beta R \frac{U_{1, C_{N T}}^{\prime}}{U_{0, C_{N T}}^{\prime}}\right]=\mathbb{E}\left[\beta R \frac{\chi_{1} / C_{N T, 1}}{\chi_{0} / C_{N T, 0}}\right]=\beta R,
$$

where $U_{t, C_{N T}}^{\prime}$ is the marginal utility at time $t$ over the consumption of non-tradables. Given the simplifying assumption that $C_{N T, t}=\chi_{t}$, the above Euler equation implies that $R=1 / \beta$. This is clearly a crude model of interest rates, but it allows us to sharpen the focus on the exchange rate: any desired changed in equilibrium currency returns have to occur via changes in expected currency appreciation.

\section{$1.1 \quad$ Financiers}

The demand and supply of bonds in different currencies by the ultimate holders/issuers rarely balances and a global financial intermediation sector exists to absorb, for a profit, these imbalances in the medium run. The intermediation sector is large but so are the global flows that it needs to absorb, the literature has therefore emphasized the limits to the sector's risk-absorption capacity.

The limits come in various forms ranging from those imposed by regulation, like capital requirements, to those arising from private contracting and the incentives to profitably use the inside capital of intermediaries given costly external financing. The literature has taken various modeling approaches to capture the essence of financial constraints. Adrian and Shin (2014) analyze the importance of Value at Risk constraints, a risk management approach used in large financial institutions as well as regulation. Amador, Bianchi, Bocola and Perri (2020) and Fanelli and Straub (2020) use direct position limits, capping the total position that foreign investors can accumulate in the asset; capturing a more direct restriction that banks often impose on 
traders. Some feature are also shared with models that feature quadratic costs of asset holdings in the utility function as a reduced form approach (Schmitt-Grohé and Uribe $(2003))$.

Here we follow a simple and tractable specification for the constrained portfolio problem that generates a demand function that captures the spirit of the limits of arbitrage theory (De Long, Shleifer, Summers and Waldmann (1990a,b); Shleifer and Vishny (1997); Gromb and Vayanos (2002)). We assume that there is a unit mass of global financial firms, each managed by a financier. Agents from the two countries are selected at random to run the financial firms for a single period. Financiers start their jobs with no capital of their own and can trade bonds denominated in both currencies. Therefore, their balance sheet consists of $q_{0}$ dollars and $-\frac{q_{0}}{e_{0}}$ yen, where $q_{0}$ is the Dollar value of Dollar-denominated bonds the financier is long of and $-\frac{q_{0}}{e_{0}}$ the corresponding value in Yen of Yen-denominated bonds. At the end of (each) period, financiers pay their profits and losses out to the households.

We assume that each financier maximizes the expected value of her firm:

$$
V_{0}=\mathbb{E}\left[\beta\left(R-R^{*} \frac{e_{1}}{e_{0}}\right)\right] q_{0}=\Omega_{0} q_{0}
$$

In the absence of frictions our financiers would simply be a veil and the optimality condition in maximization (8) would impose the household optimality criterion: $0=$ $\mathbb{E}\left[\beta\left(R-R^{*} \frac{e_{1}}{e_{0}}\right)\right]$. After taking positions but before shocks are realized, the financier can divert a portion of the funds she intermediates. If the financier diverts the funds, her firm is unwound and the households that had lent to her recover a portion $1-\Gamma\left|\frac{q_{0}}{e_{0}}\right|$ of their credit position $\left|\frac{q_{0}}{e_{0}}\right|$, where $\Gamma=\gamma\left(\operatorname{var}\left(e_{1}\right)\right)^{\alpha}$, with $\gamma \geq 0, \alpha \geq 0$. Since creditors, when lending to the financier, correctly anticipate the incentives of the financier to divert funds, the financier is subject to a credit constraint of the form:

$$
\underbrace{\frac{V_{0}}{e_{0}}}_{\substack{\text { Intermediary Value } \\
\text { in yen }}} \geq \underbrace{\left|\frac{q_{0}}{e_{0}}\right|}_{\substack{\text { Total } \\
\text { Claims }}} \quad \underbrace{\Gamma\left|\frac{q_{0}}{e_{0}}\right|}_{\substack{\text { Diverted } \\
\text { Portion }}}=\underbrace{\Gamma\left(\frac{q_{0}}{e_{0}}\right)^{2}}_{\begin{array}{c}
\text { Total divertable } \\
\text { Funds }
\end{array}} .
$$


The constrained optimization problem of the financier is:

$$
\max _{q_{0}} V_{0}=\mathbb{E}\left[\beta\left(R-R^{*} \frac{e_{1}}{e_{0}}\right)\right] q_{0}, \quad \text { subject to } \quad V_{0} \geq \Gamma \frac{q_{0}^{2}}{e_{0}} .
$$

Intuitively, given any non-zero expected excess return in the currency market, the financier would want to either borrow or lend as much as possible in Dollar and Yen bonds. The constraint limits the maximum position and therefore binds. Substituting the firm's value into the constraint and re-arranging (using $R=1 / \beta$ ), we find: $q_{0}=$ $\frac{1}{\Gamma} \mathbb{E}\left[e_{0}-e_{1} \frac{R^{*}}{R}\right]$. Integrating the above demand function over the unit mass of financiers yields the aggregate financiers' demand for assets:

$$
Q_{0}=\frac{1}{\Gamma} \mathbb{E}\left[e_{0}-e_{1} \frac{R^{*}}{R}\right]
$$

The slope parameter $\Gamma$ governs the ability of financiers to bear risks. The higher $\Gamma$, the lower the financiers' risk bearing capacity, the steeper their demand curve, and the more segmented the asset market.

UIP and CIP. To understand the economic behavior of this demand curve, let us consider two polar opposite cases. When $\Gamma=0$, financiers are able to absorb any imbalances, i.e. they want to take infinite positions whenever there is a nonzero expected excess return in currency markets. So uncovered interest rate parity (UIP) holds: $\mathbb{E}\left[e_{0}-e_{1} \frac{R^{*}}{R}\right]=0$. When $\Gamma \uparrow \infty$, then $Q_{0}=0$; financiers are unable to absorb any imbalances, i.e. they cannot take any positions, no matter what the expected returns from risk-taking. In the intermediate cases $(0<\Gamma<\infty)$, the model endogenously generates a deviation from UIP and relates it to financiers' risk taking. All else equal, expected currency excess returns are highest when financial markets are disrupted and risk bearing capacity is low, a high $\Gamma$ state.

This simple model is able to differentiate UIP from CIP. Gabaix and Maggiori (2015) show that if $\alpha>0$ then arbitrage trades, such as CIP, are not affected by the frictions and therefore CIP holds, while UIP being a risky trade fails. If, on the 
contrary, $\alpha=0$, then CIP also fails. Models of financial constraints are indeed necessary to understand CIP, since no-arbitrage asset pricing is, by its very nature, unable to understand this empirical fact. Garleanu and Pedersen (2011) introduce margin constraints in international risk-taking to generate CIP deviations. A recent and fast growing literature is shedding light on the relationship between CIP failures (their cross section, time series, and term structure properties) and exchange rate movements (see: Du, Tepper and Verdelhan (2018); Avdjiev, Du, Koch and Shin (2019); Du, Hébert and Huber (2019); Jiang, Krishnamurthy and Lustig (2018); Engel and Wu (2018)).

\subsection{Equilibrium Exchange Rate}

First consider the simple, but unrealistic, case of imbalances resulting only from trade flows, and then extend the model to imbalances arising from gross portfolio flows. To sharpen the intuition, assume for now that $\beta=\beta^{*}=1$ and $\xi_{t}=1$ for $t=0,1$. The equilibrium exchange rate is then given by:

$$
\begin{aligned}
& e_{0}=\frac{(1+\Gamma) \iota_{0}+\mathbb{E}\left[\iota_{1}\right]}{2+\Gamma}, \\
& e_{1}=\left\{\iota_{1}\right\}+\frac{\iota_{0}+(1+\Gamma) \mathbb{E}\left[\iota_{1}\right]}{2+\Gamma},
\end{aligned}
$$

where $\Gamma=\gamma \operatorname{var}\left(\iota_{1}\right)^{\alpha}$ and $\left\{\iota_{1}\right\}$ is the time-one import shock (i.e. define $\{X\} \equiv$ $X-\mathbb{E}[X]$ to be the innovation to a random variable $X)$.

Depending on $\Gamma$, the time-zero exchange rate varies between two polar opposites: the UIP-based and the financial-autarky exchange rates, respectively. Both extremes are important benchmarks of open economy analysis, and the choice of $\Gamma$ allows us to modulate our model between these two useful benchmarks. $\Gamma \uparrow \infty$ results in $e_{0}=\frac{\iota_{0}}{\xi_{0}}$, which is the financial autarky value of the exchange rate. Intuitively, financiers have so little risk-bearing capacity that no financial flows can occur between countries and, therefore, trade has to be balanced period by period. When $\Gamma=0$, UIP holds and we obtain $e_{0}=\frac{\iota_{0}+\mathbb{E}\left[\iota_{1}\right]}{2}$. Intuitively, financiers are so relaxed about risk taking that they 
would be willing to take infinite positions in currencies if there was a positive expected excess return from doing so.

\section{The Financial Frictions View of International Macroeconomics}

Having fixed ideas on a basic modeling framework, we review below what this view of international macroeconomics and finance offers for both new and classic topics in the field and how various strands of the literature have made progress on these topics.

\subsection{Financial Flows and Exchange Rates}

We focus here on the simplest form of portfolio flows from households, not so much for their realism, but because they allow for the sharpest analysis of the main forces of the model.

Assume that Japanese households have, at time zero, an inelastic demand (e.g. some noise trading) $f^{*}$ of Dollar bonds funded by an offsetting position $-f^{*} / e_{0}$ in Yen bonds. Both transactions face the financiers as counterparties. ${ }^{6}$ While we take these flows as exogenous, they can be motivated as a liquidity shock, or perhaps as a decision resulting from bounded rationality or portfolio delegation. The flow equations are now given by:

$$
\xi_{0} e_{0}-\iota_{0}+Q_{0}+f^{*}=0, \quad \xi_{1} e_{1}-\iota_{1}-R Q_{0}-R f^{*}=0
$$

The financiers' demand is still $Q_{0}=\frac{1}{\Gamma} \mathbb{E}\left[e_{0}-\frac{R^{*}}{R} e_{1}\right]$, and maintain that $\xi_{t}=R=R^{*}=$

\footnotetext{
${ }^{6}$ Technically, the maximization problem for the Japanese household is the one written before, where the portfolio flow is not a decision variable coming from a maximization, but is simply an exogenous action. The Japanese households' state-by-state budget constraint is $\sum_{t=0}^{1} \frac{Y_{N T, t}^{*}+p_{F, t}^{*} Y_{F, t}+\pi_{t}^{*}}{R^{* t}}=$ $\sum_{t=0}^{1} \frac{C_{N T, t}^{*}+p_{H, t}^{*} C_{H, t}^{*}+p_{F, t}^{*} C_{F, t}^{*}}{R^{* *}}$, where $\pi_{t}^{*}$ are FX trading profit to the Japanese, so $\pi_{0}^{*}=0, \pi_{1}^{*}=\left(f^{*}+\right.$ $\left.Q_{0}\right)\left(R-R^{*} \frac{e_{1}}{e_{0}}\right) / e_{1}$ (recall that the financiers rebate their profits to the Japanese).
} 
1 for $t=0,1$. The exchange rates at times $t=0,1$ are now:

$$
e_{0}=\frac{(1+\Gamma) \iota_{0}+\mathbb{E}\left[\iota_{1}\right]-\Gamma f^{*}}{2+\Gamma} ; \quad e_{1}=\left\{\iota_{1}\right\}+\frac{\iota_{0}+(1+\Gamma) \mathbb{E}\left[\iota_{1}\right]+\Gamma f^{*}}{2+\Gamma},
$$

where $\Gamma=\gamma \operatorname{var}\left(\iota_{1}\right)^{\alpha}$. Hence, additional demand $f^{*}$ for dollars at time zero induces a Dollar appreciation at time zero, and subsequent depreciation at time one. However, the time-average value of the Dollar is unchanged: $e_{0}+e_{1}=\iota_{0}+\iota_{1}$, independently of $f^{*}$.

An increase in Japanese demand for Dollar bonds needs to be absorbed by financiers, who correspondingly need to sell Dollar bonds and buy Yen bonds. To induce financiers to provide the desired bonds, the Dollar needs to appreciate on impact as a result of the capital flow, in order to then be expected to depreciate, thus generating an expected gain for the financiers' short Dollar positions. This is a simple example of a deep force of the model: a relative price, the exchange rate, has to move in order to equate the supply and demand of two assets, Yen and Dollar bonds intermediated by a constrained financial sector. The capital flows considered in this section are gross flows that do not alter the net foreign asset position, thus introducing a first example of the distinct role for the financiers' balance sheet from the country net foreign asset position. In the data, gross flows are much larger than net flows, and here we see a reason why they play an important role in determining the exchange rate. ${ }^{7}$

This framework can analyze concrete situations, such as large scale capital flows from developed countries into emerging market local-currency bond markets, say by US investors into Brazilian Real bonds, that put upward pressure on the receiving countries' currencies. While such flows and their impact on currencies have been paramount in the logic of market participants and policy makers, they had for a long time proven elusive in a formal theoretical analysis.

To understand the difference between the financial determination of exchange rates

\footnotetext{
${ }^{7}$ One could extend the distinction between country level positions and financiers' balance sheet further by modeling situations where not all gross flows are stuck, either temporarily or permanently, on the balance sheet of the financiers.
} 
in imperfect financial markets and the traditional macroeconomic framework, we next illustrate two polar cases that have been popular in the previous literature: the UIPbased exchange rate and the complete market exchange rate.

Financial Flows in a UIP Model. Much of the now classic international macroeconomic analysis spurred by Dornbusch (1976) and Obstfeld and Rogoff (1995) either directly assumes that UIP holds or effectively imposes it by solving a first order approximation of the model. ${ }^{8}$ The closest analog to this literature is the case in which $\Gamma=0$, such that UIP holds. In this world, financiers are so relaxed, i.e. their risk bearing capacity is so ample, about supplying liquidity to satisfy shifts in the world demand for assets that such shifts have no impact on expected returns. Consider the example of US investors suddenly wanting to buy Brazilian Real bonds; in this case financiers would simply take the other side of the investors' portfolio demand with no effect on the exchange rate between the Dollar and the Real. In fact, equation (15) confirms that if $\Gamma=0$, then portfolio flow $f^{*}$ has no impact on the equilibrium exchange rate.

Financial Flows in a Complete Market Model. Another strand of the literature has analyzed risk premia predominantly under complete markets. To highlight that the impact of flows studied here is distinct from the earlier literature, it is illustrative to consider that the exchange rate in a setup with complete markets (and no frictions) but otherwise identical to the model used here is constant at $e_{t}=\nu$, where $\nu$ is the relative Negishi weight of Japan. Under complete markets, the marginal utility of US and Japanese agents must be equal when expressed in a common currency. Intuitively, the full risk sharing that occurs under complete markets calls for Japan and the US to have the same marginal benefit from consuming an extra unit of non-tradables. This risk sharing condition takes a simple form: $\frac{\chi_{t} / C_{N T, t}}{\chi_{t}^{*} / C_{N T, t}^{*}} e_{t}=\nu$, where $\nu$ is a constant. Substitution of the conditions $C_{N T, t}=\chi_{t}$ and $C_{N T, t}^{*}=\chi_{t}^{*}$ shows that $e_{t}=\nu$, i.e. the exchange rate is constant.

The irrelevance of $f$ gross flows also extends to complete, and some incomplete,

\footnotetext{
${ }^{8}$ Intuitively, a first order approximation imposes certainty equivalence on the model and therefore kills any risk premia such as those that could generate a deviation from UIP.
} 
market models in which the exchange rate is not constant and the presence of a risk premium makes the two currencies imperfect substitutes. The intuition is that an undesired position that does not alter the net wealth of an agent/country can be frictionlessly traded out of and hence has no equilibrium consequence.

Multiple Asset Classes. Global financial markets include many asset classes beyond short-term bonds in different currencies. Investors shift their portfolios both across countries and asset classes. An important question, therefore, is studying the impact of portfolio flows across asset classes. An interesting and growing set of papers tackles this issue. Hau and Rey (2006) and Camanho, Hau and Rey (2018) study equity portfolios with partial FX hedging that generates currency flows linked to equity flows. Greenwood, Hanson, Stein and Sunderam (2020) and Gourinchas, Ray and Vayanos (2020) introduce both long-term and short-term bonds denominated in different currencies, thus providing a joint study of exchange rates and yield curve determination. These models combine frictions on yield curve intermediation, a la Vayanos and Vila (2020), with frictions on exchange rate intermediation similar to those reviewed in this chapter. They show that this setup makes progress on understanding the joint determination of term premia and currency premia. Including matching the evidence in Lustig, Stathopoulos and Verdelhan (2019) that the short-term holding-period returns of the carry trade decrease with the maturity of the bonds used to implement the trade; and the evidence in Chinn and Meredith (2004) that UIP holds for long-horizon by-and-hold trades. It is an open question for future research to also match these theories with evidence on the positions of financiers across asset classes and their joint dynamics.

Estimating the Slope of Financiers' Demand Curve. A central tenet of the framework that we have been reviewing so far is the presence of a demand curve with finite, and potentially low, elasticity. The empirical challenge therefore is measuring the slope $\Gamma$. One added challenge is that the slope is likely to vary across times and 
markets. For example, it might be higher for shallow markets like emerging market currencies than it is for major liquid currencies, and it might be higher in a crisis than it is when financial markets are functioning normally.

The literature has taken two approaches to measurement. A reduced form approach that focuses on indexation to generate plausible exogenous portfolio flows and a structural approach that imposes a model on the data to recover estimates of the slope of the demand curve.

The reduced-form literature starts with the premise that a substantial component of global capital is allocated to passive investment vehicles, like index mutual funds and exchange traded funds, that replicate benchmark indices. If these indices feature variation in their portfolio weights that is plausibly exogenous, then they generate portfolio flows that can be used to estimate the impact on asset prices. Examples of this kind of variation are: addition or deletion of index constituents, restatement of the weights due to changes in methodology, or rules for the computation of weights that have thresholds or kinks.

This empirical strategy identifies the presence of financial frictions from the fact that portfolios allocations react to arbitrary changes in the index. Models of perfect markets imply that agents would simply ignore these arbitrary changes, since nothing has happened to the fundamentals, and keep their total portfolio unchanged. Once the inflow occurs, the appreciation could be potentially due to fundamental macro forces, rather than the direct impact on the financial sector. The timing and duration of the impact and the fact that ex-post there are no systematic patterns in the fundamentals are an indication that the effect is likely to arise from the financial side.

Hau, Massa and Peress (2010) show that, following a one-off restating of the weights of the MSCI World Equity Index, countries that as a result experienced capital inflows (because their weight in the index increased) saw their currencies appreciate. They find that the sixteen most upweighted currencies appreciate relative to the seventeen most downweighted countries on average by more than 2 percent.

Pandolfi and Williams (2019) use an identification strategy based on a quirk of 
one of the most followed indices of emerging-market local-currency sovereign debt, the J.P. Morgan Government Bond Index-Emerging Markets Global Diversified (GBI-EM Global Diversified). The index providers realized that the distribution of outstanding market value of sovereign debt by country is so skewed that a few large economies, like Brazil and Mexico, would account for the vast majority of the index thus nullifying its purpose as a broad benchmark. The index, therefore, is built with a cap so that no country can account for more than 10 percent of its value at any point in time. Pandolfi and Williams (2019) exploit the fact that since the index still has to sum to 100 percent, this means that oscillations in the market value of countries above the cap have to be reflected in the weight of those countries below the cap for the sole purpose of mechanical re-weighting. Using this variation, they estimate that a 1 percent inflow - relative to the market value of the sovereign bonds included in the index - leads to a close to 3 percent appreciation in the exchange rate against the dollar.

Broner, Martin, Pandolfi and Williams (2020) exploit episodes of large sovereign debt inflow shocks in six emerging countries (Colombia, Czech Republic, Mexico, Nigeria, Romania, and South Africa). Specifically, they take advantage of sudden and unanticipated announcements of country inclusions in two major sovereign debt indexes: the Citigroup World Government Bond Index (WGBI) and the J.P. Morgan Government Bond Index Emerging Markets (GBI-EM). They find that a 1 percent inflow, relative to GDP, leads to a 0.9 percent appreciation in the exchange rate.

The structural literature imports industrial organization methodologies to back out demand elasticities. This approach is complementary to the reduced-form discussed above. It exploits more of the variation of the data, thus being able to differentiate between short run and long-run elasticities, by imposing more structure via a modeling framework. This type of approach is still developing in international macro-finance with recent contributions by Koijen and Yogo (2020), Jiang, Richmond and Zhang (2020b), and Pellegrino, Spolaore and Wacziarg (2020). In particular, Koijen and Yogo (2020) find an important role for market segmentation and capital flows in determining exchange rates. They estimate a portfolio model on bilateral asset holdings at the 
country level for bonds and equities jointly with asset prices (exchange rates, bond yields, and equity prices) and the supply (issuance level) of these assets. They also find a convenience yield on US (dollar) assets, a topic covered at the end of this chapter.

The Exchange Rate Disconnect. The Meese and Rogoff (1983) result on the inability of economic fundamentals such as output, inflation, exports and imports to predict, or even contemporaneously co-move with, exchange rates has had a chilling and long-lasting effect on theoretical research in the field (see Obstfeld and Rogoff (2001)). Imperfect financial intermediation proposes a view of global currency markets in which the exchange rate disconnect is natural because the exchange rate is pinned down by financial forces that might only have a very indirect connection with macro fundamentals. Following the framework developed so far, both the risk bearing capacity $\Gamma$ and the balance sheet $Q$, itself affected by flows $f$, are determinants of exchange rates.

Intuitively, a disconnect occurs because economies with identical fundamentals feature different equilibrium exchange rates depending on the incentives of the financiers to hold the resulting (gross) currency imbalances. Further, exchange rate fundamental volatility (i.e. due to fundamental shocks) can be amplified by financial imperfections since it endogenously tightens financial constraints (recall that $\Gamma$ depends itself on the volatility of the exchange rate), thus leading to more exchange rate excess sensitivity to financial shocks like the $f$ flows. ${ }^{9}$

Recently, evidence has been building in favor of these new financial channels. In addition to the instrumental variable approach (Hau, Massa and Peress (2010); Pandolfi and Williams (2019); Broner, Martin, Pandolfi and Williams (2020)) discussed earlier, Froot and Ramadorai (2005); Adrian, Etula and Groen (2011); Hong and Yogo (2012); Kim, Liao and Tornell (2014), and Adrian et al. (2014) find that flows, financial conditions, and financiers' positions provide information about expected currency returns. Froot and Ramadorai (2005) show that medium-term variation in expected

\footnotetext{
${ }^{9}$ Along these lines, Fang and Liu (2021) develop a quantitative model of endogenous volatility of exchange rates and financial constrains and provide related empirical support for a a feedback loop between exchange rate volatility and the tightness of the constraints.
} 
currency returns is mostly associated with capital flows, while long-term variation is more strongly associated with macroeconomic fundamentals. Koijen and Yogo (2020) provide a structural decomposition finding a role for both fundamentals and financial forces. Hong and Yogo (2012) show that speculators' positions in the futures currency market contain information that is useful, beyond the interest rate differential, to forecast future currency returns. Adrian, Etula and Groen (2011); Adrian, Etula and Shin (2014) show that empirical proxies for financial conditions and the tightness of financiers' constraints help forecast both currency returns and exchange rates. Kim, Liao and Tornell (2014) show that information extracted from the speculators' positions in the futures currency market helps to predict exchange rate changes at horizons between 6 and 12 months. Lilley, Maggiori, Neiman and Schreger (2020) show that, starting with the global financial crisis, US foreign bond purchases are connected contemporaneously to the broad dollar exchange rate.

Itskhoki and Mukhin (2021) show that the exchange rate disconnect can be quantitatively explained by a model that features currency market segmentation and an otherwise standard real business cycle setup with home bias in consumption. They show that the exchange rate has to have a substantial component of its movement explained by financial shocks rather than monetary or productivity shocks. They show that nominal rigidities, which are covered in the next subsection below, improve the quantitative performance of the model but are not at the core of the exchange rate disconnect phenomenon. Itskhoki and Mukhin (2020) show that a similar framework can also shed a different light on the evidence by Mussa (1986) that real exchange rates inherit, at short horizons, the properties of nominal exchange rates. This evidence is most often associated with the importance of nominal rigidities rather than market segmentation.

Open Questions. If capital flows are to play a prominent role in pinning down exchange rates, then a natural question is what drives these flows and how they should be modeled. They might be driven by a combination of liquidity needs, risk sharing, 
behavioral and institutional biases such as search for yield, taxes and regulation, or motives yet to be uncovered. The literature is likely to make much progress in this investigation and move past preliminary answers that treat these flows as exogenous shocks.

Bacchetta and Van Wincoop (2010), Bacchetta, van Wincoop and Young (2020a), and Bacchetta, Tieche and van Wincoop (2020b) offer an empirical and theoretical analysis of infrequent portfolio rebalancing. They document that investment funds, in particular mutual funds, trade with a delay with respect to shocks and adjust their portfolio only gradually compared to a target/benchmark portfolio. They show how this type of flows can help rationalize UIP deviations and exchange rate volatility.

A particularly fruitful research avenue is likely to be analyzing the risk-taking of global financial intermediaries. For example, Morelli, Ottonello and Perez (2019) collect security-level data on global financial institutions holdings of emerging market debt and use an identification strategy based on exposure to Lehman's bankruptcy to show that these institutions' financial constraints play an important role in determining asset prices in emerging markets.

It seems likely that data on global capital allocations by financial institutions will continue to improve and shed more light on global macro patterns. Maggiori, Neiman and Schreger (2020) analyze the allocations of global bond portfolios of mutual funds and ETFs focusing specifically on the currency of the bonds. They find a strong home-currency bias: funds disproportionally invest in bonds denominated in the funds' domestic currency even when the issuer of the bond is a foreign entity. Coppola, Maggiori, Neiman and Schreger (2020) show how to systematically unwind positions the immediate destination of which is a tax haven country for both bonds and equities, thus providing a better estimate of bilateral investment positions. ${ }^{10}$

\footnotetext{
${ }^{10}$ Coppola, Maggiori, Neiman and Schreger (2020) expand the data to include the universe of securitylevel holdings by US insurance companies and the Norwegian sovereign wealth fund. Maggiori, Neiman and Schreger (2019) additionally investigate the role of the dollar in the loan market, in official reserves, and in goods invoicing. The estimates in support of this research are made available at www. globalcapitalallocation. com.
} 
Currency trading also involves derivatives, such as currency forwards and swaps. Regulations introduced in many advanced economies in the aftermath of the global financial crisis require the disclosure of derivative transactions (e.g. the European Market Infrastructure Regulation (EMIR)). The resulting data repositories offer an opportunity for researchers to understand FX derivatives trading. Cenedese, Della Corte and Wang (2020) use the EMIR data to document that balance sheet constraints by dealers cause CIP deviations. For mutual funds, Sialm and Zhu (2020) use public disclosure of US-domiciled funds to document currency trading via forwards in addition to foreign-currency bonds. They find that, on average, funds use derivatives to hedge foreign currency exposure, but that there is heterogeneity in terms of emerging markets vs developed market currencies and style of the fund.

\subsection{Production and Sticky Prices: Exchange Rates as Shock Absorbers or Sources of Instability}

A part of the literature on exchange rates and financial frictions has either considered partial equilibrium models or endowment economies. A general equilibrium production setting shows the important role that exchange rates can have in transmitting financial distortions and pressures coming from financial flows to the real economy. Thus providing theoretical support for the argument often articulated by emerging market policy makers that open capital markets and floating exchange rates seldom perform the shock absorption role highlighted by traditional macroeconomic analysis. To build up to this intuition, let us consider alternative ways to close the basic setup we have been analyzing.

Endowment Economy Let all output stochastic processes $\left\{Y_{N T, t}, Y_{H, t}, Y_{N T, t}^{*}, Y_{F, t}\right\}_{t=0}^{1}$ be exogenous strictly-positive endowments. Assuming that all prices are flexible and that the law of one price (LOP) holds, one has: $p_{H, t}=p_{H, t}^{*} e_{t}$, and $p_{F, t}=p_{F, t}^{*} e_{t}$.

Summing US and Japanese demand for US tradable goods $\left(C_{H, t}=\frac{a_{t}}{p_{H, t}}\right.$ and $C_{H, t}^{*}=$ 
$\frac{\xi_{t} e_{t}}{p_{H, t}}$, respectively), we obtain the world demand for US tradables: $D_{H, t} \equiv C_{H, t}+C_{H, t}^{*}=$ $\frac{a_{t}+\xi_{t} e_{t}}{p_{H, t}}$. Clearing the goods market, $Y_{H, t}=D_{H, t}$, yields the equilibrium price in dollars of US tradables: $p_{H, t}=\frac{a_{t}+\xi_{t} e_{t}}{Y_{H, t}}$. An entirely similar argument yields: $p_{F, t}^{*}=\frac{a_{t}^{*}+\frac{\iota_{t}}{e_{t}}}{Y_{F, t}}$.

Production Without Price Rigidities. Let us introduce a minimal model of production. While we maintain the assumption that non-tradable goods in each country are given by endowment processes, we now assume that tradable goods in each country are produced with a technology linear in labor with unit productivity. In each country, labor $L$ is supplied inelastically and is internationally immobile.

Profit maximization at the firm level yields a Dollar wage in the US of $w_{H, t}=p_{H, t}$. Under flexible prices, goods market clearing then implies full employment $Y_{H, t}=L$ and a US tradable price in dollars of: $p_{H, t}^{\circ}=\frac{a_{t}+\xi_{t} e_{t}}{L}$, where the circle in $p^{\circ}$ denotes a frictionless quantity. Likewise, for Japanese tradables the equilibrium features both full employment $Y_{F, t}=L$ and a Yen price of: $p_{F, t}^{* \circ}=\frac{a_{t}^{*}+\iota_{t} / e_{t}}{L}$.

Production With Price Rigidities. Let us now assume that wages are "downward rigid" in domestic currency at a preset level of $\left\{\bar{p}_{H}, \bar{p}_{F}^{*}\right\}$, where these prices are exogenous (see also Schmitt-Grohé and Uribe (2016)). Let us further assume that firms do not engage in pricing to market, so that prices are sticky in producer currency (PCP). Firm profit maximization then implies that: $p_{H, t}=\max \left(\bar{p}_{H}, p_{H, t}^{\circ}\right)$; or more explicitly: $p_{H, t}=\max \left(\bar{p}_{H}, \frac{a_{t}+e_{t} \xi_{t}}{L}\right)$. Hence:

$$
Y_{H, t}=\min \left(\frac{a_{t}+e_{t} \xi_{t}}{\bar{p}_{H}}, L\right)
$$

If demand is sufficiently low $\left(a_{t}+\xi_{t} e_{t}<\bar{p}_{H} L\right)$, then output is demand-determined (i.e., it depends directly on: $e_{t}, \xi_{t}$, and $a_{t}$ ) and there is unemployment: $L-Y_{H, t}>0$. Notice that in this case the exchange rate has an expenditure-switching effect: if the Dollar depreciates $\left(e_{t} \uparrow\right)$, unemployment falls and output expands in the US. Intuitively, since US tradables' prices are sticky in dollars, these goods become cheap for Japanese consumers to buy when the Dollar depreciates. In a world that is demand constrained, 
this expansion in demand for US tradable is met by expanding production, thus raising US output and employment. A similar expression and mechanism apply to Japanese tradables:

$$
Y_{F, t}=\min \left(\frac{a_{t}^{*}+\iota_{t} / e_{t}}{\bar{p}_{F}^{*}}, L\right)
$$

The expenditure switching role of exchange rates has been central to the Keynesian analysis of open macroeconomics (Dornbusch (1976); Obstfeld and Rogoff (1995)).

The financial determination of exchange rates has real consequences. Let us reconsider our earlier example of a sudden inflow of capital from US investors into Brazilian Real bonds. The exchange rate in this economy with production and sticky prices is still characterized by equation (15). As previously discussed, the capital inflow in Brazil causes the Real to appreciate and, ${ }^{11}$ if the flow is sufficiently strong ( $f$ sufficiently high) or the financiers' risk bearing capacity sufficiently low ( $\Gamma$ sufficiently high), the appreciation (the increase in $e_{0}$ ) can be so strong as to make Brazilian goods uncompetitive on international markets; the corresponding fall in world demand for Brazilian output $\left(\downarrow C_{H}^{*}=\frac{\iota_{0}}{e_{0} \bar{p}_{F}^{*}}\right)$ causes an economic slump in Brazil with both falling output and increasing unemployment. ${ }^{12}$

An alternative assumption is that prices are sticky in the export destination currency. To make the point sharp, assume that prices for US tradable goods are exogenously set at $\left\{\bar{p}_{H}, \bar{p}_{H}^{*}\right\}$ in dollars in the US and in yen in Japan, respectively. Under Local Currency Pricing (LCP) the value of the exchange rate is the same as under Producer Currency Pricing (PCP), but US tradable output does not depend on the exchange rate: $Y_{H, t}=\min \left(\frac{a_{t}}{\bar{p}_{H}}+\frac{\xi_{t}}{\bar{p}_{H}^{*}}, L\right)$. LCP helps to further the disconnect between the exchange rate and fundamentals by preventing output in the tradable sector from responding to the exchange rate. ${ }^{13}$ Another possibility is that goods might be priced

\footnotetext{
${ }^{11}$ When $\alpha=0, \frac{\partial e_{0}}{\partial f}=-\frac{\Gamma}{2+\Gamma}<0$. More generally, a sufficient condition for this effect is that $\alpha$ is small.

${ }^{12}$ The Brazilian Finance Minister Guido Mantega complained, as reported in Forbes Magazine (2011), that: "We have to face the currency war without allowing our productive sector to suffer. If we allow [foreign] liquidity to [freely] enter [the economy], it will bring the Dutch Disease to the economy."

${ }^{13}$ Devereux and Engel (2003) stressed the absence of exchange rate effects on output under LCP. The empirical evidence shows that, in practice, a combination of PCP, LCP and DCP are present in the data (see Burstein and Gopinath (2015) for a review).
} 
in neither the producer nor the destination currency, but in a third country's currency (most often the dollar). Basu, Boz, Gopinath, Roch and Unsal (2020) analyze the interaction between segmented currency markets and dollar currency pricing in the goods market.

\subsection{Foreign Exchange Intervention}

The model of exchange rates considered so far has emphasized the central role of financial forces and in particular capital flows in the determination of exchange rates. One very prominent type of flow is currency intervention by the official sector.

Large-scale currency interventions have recently been undertaken by the governments of Switzerland, Israel, and the Czech Republic, in addition to many emerging markets. Figure 2 highlights the grand scale on which these FX operations have been conducted. These governments aimed to relieve their currency appreciation in the face of turmoil in financial markets. The policymakers at the respective institutions expressed the view that interventions successfully weakened the exchange rate and boosted the real economy.

For example, Israels' central bank governor Stanley Fisher remarked: "I have no doubt that the massive purchases [of foreign exchange] we made between July 2008 and into 2010 [...] had a serious effect on the exchange rate which I think is part of the reason that we succeeded in having a relatively short recession." Levinson (2010). ${ }^{14}$

Thomas Jordan, the governor of the Swiss National Bank, remarked in his 2020 Camdessus Lecture at the IMF that: "in Switzerland the upward pressure on the franc was the main reason for the at times very low inflation. Against this backdrop, for us, foreign exchange market interventions were and still are the most direct and thus the most effective instrument besides the negative interest rate. [...] Our experience shows that foreign exchange market interventions and the negative interest rate are essential for a small open economy with a safe-haven currency in a global low interest

\footnotetext{
${ }^{14}$ In context the expression "a serious effect on the exchange rate" is understood to mean prevented a strong appreciation of the Shekel.
} 


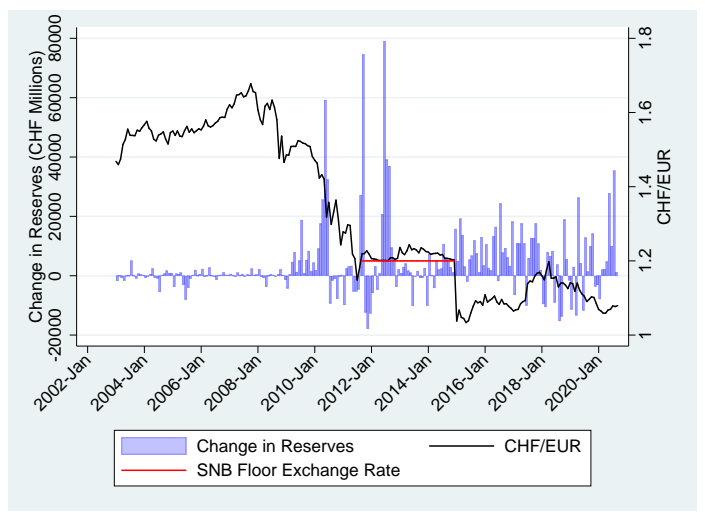

(a) Swiss National Bank (SNB) Change in Reserves and the CHF/EUR Exchange rate

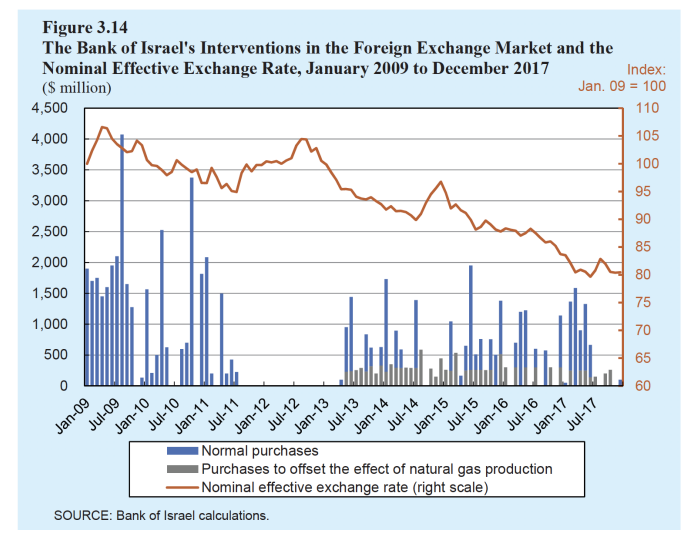

(b) Bank of Israel (BoI) FX Purchases and the Shekel Exchange Rate

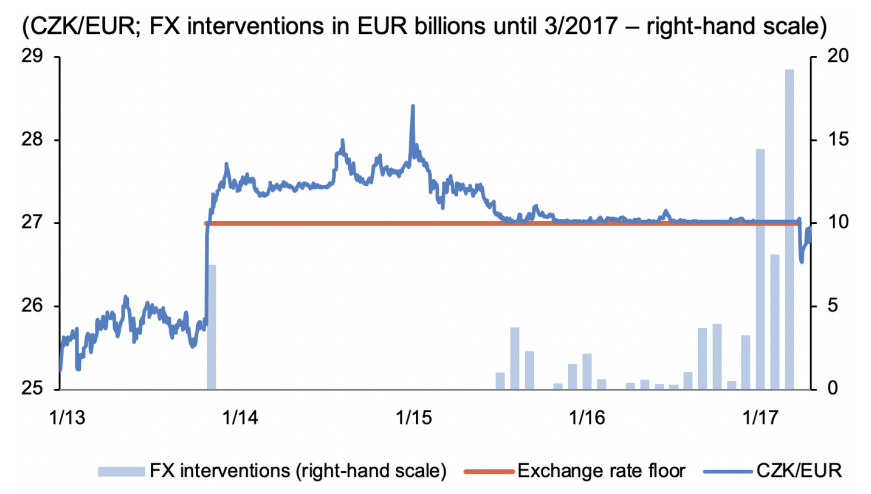

(c) Czech National Bank (CNB) FX Purchases and the CZK/EUR Exchange Rate

Figure 2: Recent Episodes of FX Intervention. Panel A plots the CHF/EUR nominal exchange rate (right axis) and the change in reserves held by the Swiss National Bank (SNB). Source: FRED series on Relevant Foreign Currency Positions of the Swiss National Bank. Panel B plots monthly FX purchases by the Bank of Israel (BoI) (left axis) and the Shekel nominal exchange rate (a decrease is a Shekel appreciation). Source: reproduced here courtesy of Bank of Israel. Panel C plots FX interventions by the Czech National Bank (CNB) (right scale) and the CZK/EUR exchange rate. Source: reproduced here courtesy of Czech National Bank. 
rate environment. The combination of these two monetary policy instruments is more effective and results in fewer undesirable side-effects overall than concentrating on just one of them." Jordan (2020).

The theoretical literature on FX intervention has recently made much progress in understanding both under which conditions foreign exchange rate intervention can be effective and how it should be used optimally (see: Cavallino (2019); Amador, Bianchi, Bocola and Perri (2020); Fanelli and Straub (2020); Davis, Devereux and Yu (2020); Hassan, Mertens and Zhang (2020)). Since the companion handbook chapter by Bianchi and Lorenzoni (2021) provides a review of optimal policy including FX intervention, here we focus on understanding why in a model of limited risk-bearing capacity FX intervention is effective and its relation to private flows. ${ }^{15}$ The limited risk-bearing capacity of the financiers is at the core of the effects of FX intervention on exchange rates. Indeed, Backus and Kehoe (1989) show that in a general class of models in which currencies are imperfect substitutes due to risk premia, but in which importantly there are no financial frictions, sterilized FX interventions have no effect on the exchange rate.

Returning to our illustrative framework, we set most parameters at 1 for notational simplicity: e.g. $\iota_{0}=\xi_{t}=a_{t}=a_{0}^{*}=\beta=\beta^{*}=1$. We allow $\iota_{1}$ to be stochastic (keeping $\mathbb{E}\left[\iota_{1}\right]=1$, and setting $a_{1}^{*}=\iota_{1}$ for symmetry) so that currency trading is risky.

At time 0 , the Japanese government intervenes in the currency market vis-à-vis the financiers: it buys $q^{*}$ dollars and sells $q^{*} / e_{0}$ yen. The analogy with private flows discussed in Section 2.1 shows that we obtain the following result (as the government creates a flow $f^{*}=q^{*}$ in the currency market): If the Japanese government buys $q^{*}$ dollars and sells $q^{*} / e_{0}$ yen at time 0 , the exchange rates satisfy $e_{0}=1-\frac{\Gamma}{2+\Gamma} q^{*}$, and $e_{1}=1+\frac{\Gamma}{2+\Gamma} q^{*}+\left\{\iota_{1}\right\}$, with $\Gamma=\gamma \operatorname{var}\left(\iota_{1}\right)^{\alpha}$.

In the absence of frictions, if $\Gamma=0$, there is no effect of the intervention on the

\footnotetext{
${ }^{15}$ There is also an extensive literature on financial frictions and pecuniary externalities, especially in the context of emerging markets, which we do not review here. See: Caballero and Krishnamurthy (2001); Mendoza (2010); Bianchi (2010); Brunnermeier and Sannikov (2015); Dávila and Korinek (2017); Caballero and Simsek (2020).
} 
exchange rate. Correspondingly, the potency of the intervention is strictly increasing in the severity of the frictions: the higher the $\Gamma$, the more the exchange rate moves for a given size of the intervention. Intuitively, FX intervention is, all else equal, more powerful in shallow markets like emerging economies, or when financial markets are deeply constrained, like in a crisis or flight to safety episode.

One way to give theoretical foundations to the statements by policymakers reported above is to return to the model with production and PCP. Assume that in the short run, i.e. period $t=0$, Japanese tradables' prices are sticky in domestic currency; prices are flexible in the long run, i.e. period $t=1$. We postulate that at time zero the price is downward rigid at a level $\bar{p}_{F}^{*}$ that is sufficiently high as to cause unemployment in the Japanese tradable sector. US tradable prices are assumed to be flexible. This captures a situation in which one country is in a recession, with high slack capacity and unemployment, so much so that its output is demand driven. A Japanese government currency intervention, whereby the government buys $q^{*} \in\left[0, \bar{q}^{*}\right]$ worth of Dollar bonds and sells $q^{*} / e_{0}$ yen bonds at time zero, depreciates the Yen and increases Japanese output. $\bar{q}^{*}$ is the smallest intervention that restores full employment in Japan. The intervention distorts consumption with the consumption shares determined by: $\frac{C_{H, t}^{*}}{L}=s_{t}^{*}$ and $\frac{C_{F, t}}{Y_{F, t}}=1-s_{t}^{*}$ with $s_{t}^{*}=\frac{e_{t}}{1+e_{t}}$ for $t=0,1$.

There are two preconditions for this intervention analysis. The first one is that prices are sticky (fixed) in the short run at a level that generates a fall in aggregate demand and induces an equilibrium output below the economy's potential. This condition, i.e. being in a demand driven state of the world, is central to the Keynesian analysis in which a depreciation of the exchange rate leads to an increase in output via an increase in export demand. If this condition is satisfied, a first order output loss would occur even in a world of perfect finance. The second precondition is that financial markets are imperfect, i.e. $\Gamma>0$. Recall that the ability of the government to affect the time-zero exchange rate is inversely proportional to $\Gamma$. When markets are frictionless $(\Gamma=0)$ the government FX policy has no effect on the time-zero exchange rate, even if prices are sticky, because financiers would simply absorb the intervention 
without requiring a compensation for the resulting risk.

The model suggests that intervention is best used in countries with relatively shallow FX markets, or in those situations when financial intermediaries are temporarily very constrained. It also clarifies the relevant stock of assets to affect: the balance sheet of financial institutions. The earlier literature on portfolio balance had instead focused on the stock of outstanding assets in different currencies, which is often much bigger than those held by financial players, making it quantitatively less plausible that interventions could be effective. Finally, the model stresses the nature of FXI as a risk transfer from the private sector to the central bank. Since the key point is to transfer the risk, FXI can be implemented with derivatives (like currency swaps and forwards) without necessarily having to have the bonds themselves on the balance sheet of the central bank. Indeed, in recent years interventions in the derivatives market have become commonplace for most central banks.

FX intervention might also be combined with forms of capital controls that increase market segmentation. A simple way to explore this idea is to introduce a proportional (Japanese) government tax on each financier's profits. Recall the imperfect intermediation problem in Section 1.1, we now assume that the after-tax value of the intermediary is $V_{t}(1-\tau)$, where $\tau$ is the tax rate. The financiers' optimality condition, derived in a manner entirely analogous to the optimization problem in equation (10), is now: $Q_{0}=\frac{\mathbb{E}\left[e_{0}-e_{1} \frac{R^{*}}{R}\right](1-\tau)}{\Gamma}$. This is equivalent to changing $\Gamma$ to an effective $\Gamma^{\mathrm{eff}} \equiv \frac{\Gamma}{1-\tau}$, so that the financiers' demand can be rewritten as $Q_{0}=\frac{\mathbb{E}\left[e_{0}-e_{1} \frac{R^{*}}{R}\right]}{\Gamma^{\mathrm{eff}}}$. Recall that the effect of currency intervention on the exchange rate is bigger the lower the financiers' risk bearing capacity (the higher the $\Gamma$ ). It follows that a tax on finance or a capital control, by implicitly reducing risk-bearing capacity, increases the potency of FX intervention.

There are, of course, many other rationales for intervening, including at the opposite end of the spectrum preventing contractionary exchange rate depreciations. Intervention might target more complex dynamics of the exchange rate than the level analyzed above; for example, intervention might target inefficiently high volatility of the exchange rate rather than the level. However, the limits to currency market in- 
termediation remain a core foundation for this policy. Recently, the IMF moved its traditional policy stance that discouraged the use of FX intervention. The new Integrated Policy Framework of the IMF includes FX intervention as a stabilization tool to be used jointly with monetary policy, macro-prudential regulation, and capital controls. Basu, Boz, Gopinath, Roch and Unsal (2020) provide a conceptual model as a foundation of the new IMF policy framework in which FX intervention is predicated on the presence of segmented currency markets.

Evidence and Some Practical Considerations. Empirical evidence on the effectiveness of FX intervention is limited by the thorny issue of endogeneity. For example, if central banks intervene to stem appreciation, even successful interventions that prevent (further) appreciation might appear to be counterproductive in an analysis that does not account for the endogeneity. The concern is apparent in Figure 2. In all three cases, the central banks are intervening against currency appreciation and stop or slow the intervention when they perceive the exchange rate to be above their targeted level. ${ }^{16}$ A further consideration is the size and duration of the intervention. Small interventions at high frequency might have very different outcomes from the protracted and large interventions observed in recent years by Switzerland and Israel and discussed above.

An early empirical literature, that mostly focused on interventions of smaller size, found mixed results and is summarized by Sarno and Taylor (2001). A classic study by Dominguez and Frankel (1993a,b) finds empirical support for the effect of foreign exchange rate intervention via a portfolio balance channel. More recently, Blanchard, de Carvalho Filho and Adler (2014), Fratzscher, Gloede, Menkhoff, Sarno and Stöhr (2019b), Fratzscher, Menkhoff, Sarno, Schmeling and Stoehr (2019a), and House, Proebsting and Tesar (2021) find evidence that FX intervention is effective.

There are many open areas for future work. On the empirical side, more policy

\footnotetext{
${ }^{16}$ For Israel and the Czech Republic the figure uses FX purchases by the central bank. For Switzerland, instead, it uses changes in the total value of FX reserves held at the central bank.
} 
evaluation that makes progress on endogeneity is a crucial endeavor. On the theoretical side, many features that are of important practical consideration are mostly absent from the current models. One particularly important area is the political economy of these new tools and the chance that they might be abused by policymakers. One might conjecture that FX intervention is less likely to be abused than capital controls to generate fiscal revenue since the revenue is uncertain and might even turn out to be negative. The potential losses of FX intervention bring up the possibility that the central bank might lose its independence. Similarly, vast reserve accumulation and management come with issues on how they are allocated, and whether the allocation should include ethical considerations in addition to pure return and risk ones. These are likely to be important themes for the future literature.

\subsection{The Carry Trade and Financial Constraints}

The carry trade is a popular investment strategy that invests in currencies with high interest rates and funds the trade in those with low interest rates. It is of interest to academics both because it is a driver of capital flows due to its popularity in the financial industry, and because its profitability is connected with a failure of the UIP condition. $^{17}$

Lustig, Roussanov and Verdelhan (2011) document the profitability and risk of the carry trade by sorting currencies monthly in buckets according to the level of their nominal interest rate. They show that, on average, the buckets containing currencies with higher interest rates tend to have higher returns than those containing the lower interest-rate currencies. Fig 3 plots the cumulative return of investing in the highest interest-rate bucket while funding the trade with the lowest interest-rate bucket. It illustrates three common patterns that the empirical literature has documented: (i) that the carry trade is on average profitable, (ii) that the trade does badly in bad times and periods of financial stress, and (iii) the gains accumulate slowly over time

\footnotetext{
${ }^{17}$ One sign of the popularity of this currency trading strategy is the availability of Exchange Traded Funds (ETFs) that replicate the carry trade (e.g. Invesco DB G10 Currency Harvest Fund).
} 
while losses tend to be large and sudden. ${ }^{18}$

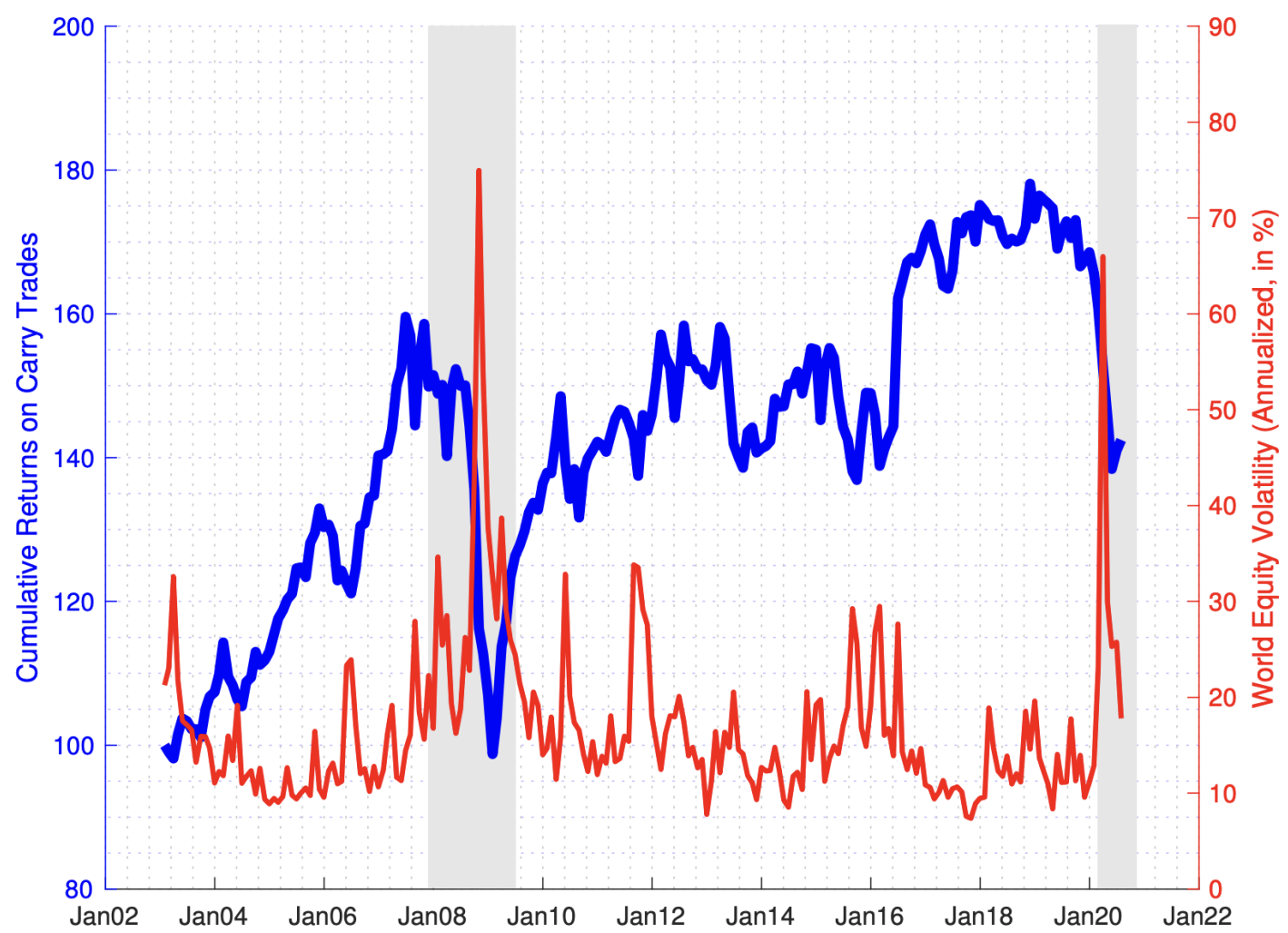

Figure 3: Carry Trade: Profitability and Risk. The blue thick line plots (left axis) the cumulative return of the carry trade. The trade is defined here as investing (equally weighted) in a basket of high interest-rate currencies while shorting a basket of low interestrate currencies. The sample includes only developed countries currencies. The red thin line plots realized volatility of world equity markets. Source: the Figure is reproduced courtesy of Adrien Verdelhan from his slides for the Stanford Big-Data Initiative in International Macro-Finance.

The carry trade and the related stylized facts have become one of the benchmarks for international macro models. The first generation of models explained the carry trade under complete and frictionless markets by endogenously generating a depreciation of high interest-rate currencies with respect to low interest-rate currencies in bad times.

\footnotetext{
${ }^{18}$ A large empirical literature has followed the classic study of Lustig, Roussanov and Verdelhan (2011) both further documenting the empirical performance of the carry trade and testing factor models that could explain currency returns. For example: Menkhoff, Sarno, Schmeling and Schrimpf (2012); Lettau, Maggiori and Weber (2014); Corte, Riddiough and Sarno (2016); Verdelhan (2018); Richmond (2019). Adrien Verdelhan makes the data on currency portfolios available to other researchers at http://web.mit.edu/adrienv/www/ Data.html.
} 
The common theme is that bad times are those in which the stochastic discount factor (SDF) is high. Verdelhan (2010) uses a habit-formation model, Colacito and Croce (2011) a long-run risk model, Hassan (2013) a country size model, and Farhi and Gabaix (2016) a rare disaster model.

It is useful to illustrate how a segmented market model rationalizes the carry trade patterns. For intuition, let us first use the most basic model and then extend it to a setup with shocks to the financiers' risk-bearing capacity ( $\Gamma$ shocks) capable of addressing time variation patterns.

Let us re-immerse ourselves in the basic version of the model under financial autarky. When the financiers have zero risk-bearing capacity $(\Gamma=\infty)$, suppose that Japan has a $0 \%$ interest rate while the US has a $2 \%$ interest rate, and that all periods $(t=0, \ldots, T)$ are ex-ante identical with $\xi_{t}=1$ and $\iota_{t}$ a martingale. Thus, we have $e_{t}=\iota_{t}$, and the exchange rate is a random walk $e_{0}=\mathbb{E}\left[e_{1}\right]=\ldots=\mathbb{E}\left[e_{T}\right]$. If exchange rates are a random walk and countries have different interest rates, then there is a profitable carry trade. Linearizing, we can write the realized return as $\Delta e_{t+1}+r_{t}^{*}-r_{t}$ that incorporates both the exchange rate gains and interest rate differential. The martingale property imposes $\mathbb{E}\left[\Delta e_{t+1}+r_{t}^{*}-r_{t}\right]=r_{t}^{*}-r_{t}$, such that expected returns coincide with the interest rate differential.

Imagine relaxing the financial constraint, a small financier with some available risk-bearing capacity could take advantage of this trading opportunity and pocket the $2 \%$ interest rate differential. As the financial sector risk-bearing capacity expands $(\Gamma$ becomes smaller, but still positive), this carry trade becomes less profitable but does not disappear entirely unless $\Gamma=0$, in which case the UIP condition holds. Intuitively, the carry trade in this basic segmented currency model reflects the risk compensation necessary to induce the financiers to intermediate global financial flows.

To see this more formally, recall that interest rates in the basic parametrization are given by $R=\beta^{-1}$ and $R^{*}=\beta^{*-1}$. Consider the case in which $R<R^{*}$ so that the Dollar is the Yen is long currency and the Dollar the short currency of this carry trade. The return of the carry trade is: $R^{c} \equiv \frac{R^{*}}{R} \frac{e_{1}}{e_{0}}-1$. For notational convenience we 
define the carry trade expected return as $\bar{R}^{c} \equiv \mathbb{E}\left[R^{c}\right]$. Let us maintain for simplicity that $\xi_{t}=1$. The expected return to the carry trade is then:

$$
\bar{R}^{c}=\Gamma \frac{\frac{R^{*}}{R} \mathbb{E}\left[\iota_{1}\right]-\iota_{0}}{\left(R^{*}+\Gamma\right) \iota_{0}+\frac{R^{*}}{R} \mathbb{E}\left[\iota_{1}\right]}, \quad \text { where } \quad \Gamma=\gamma \operatorname{var}\left(\iota_{1}\right)^{\alpha}
$$

The carry trade return is bigger when the return differential $R^{*} / R$ is larger and when finance is more imperfect (higher $\Gamma$ ). The prediction about the size of interest rate differentials is interesting in light of a compression of interest rates toward zero in most advanced economies past 2007.

Indeed, there is evidence of changes in the dynamics of exchange rates and currency returns in the last decade of low interest rate environment. Ilzetzki, Reinhart and Rogoff (2020a) point to a decline in exchange rate volatility due to monetary policy convergence (toward the ZLB) in advanced economies, while Lilley and Rinaldi (2020) point to exchange rates, rather than interest rate differentials, compensating investors for aggregate risk post 2007. At the same time the emergence of CIP deviations post 2007 signals a tightness in financial intermediation capacity perhaps connected to new regulation on global risk taking.

To gain further intuition on the above result, consider first the case where $\iota_{0}=\mathbb{E}\left[\iota_{1}\right]$. The first-order approximation to $\bar{R}^{c}$ in the case of a small interest rate differential $R^{*}-R$ is: $\bar{R}^{c}=\frac{\Gamma}{2+\Gamma}\left(R^{*}-R\right)$. Notice that we have both $\frac{\partial \bar{R}^{c}}{\partial \Gamma}>0$ and $\frac{\partial \bar{R}^{c}}{\partial\left(R^{*}-R\right)}>0$, so that the profitability of the carry trade increases the more limited the risk-bearing capacity of the financiers and the larger the interest rate differential.

The effects of broadly defined "global risk aversion", here proxied by $\Gamma$, on the profitability of the carry trade have been central to the empirical analysis of, for example, Brunnermeier, Nagel and Pedersen (2009). This two period model, however, cannot illustrate the dynamics of state-dependent expected currency returns. Figure 3 illustrates that the carry trade crashed during the global financial crisis and then again during the market collapse in March 2020 in the early phase of the covid-19 pandemic. Ex-post returns were high emerging from the global financial crisis, a pattern 
consistent with expected returns being high after a crash (for more general evidence, see Brunnermeier, Nagel and Pedersen (2009)).

The exposure of the carry trade to financial disruptions. We have shown above that the carry trade is more profitable the lower the risk-bearing capacity of the financiers. We next formally account for shocks to such capacity in the form of a stochastic $\Gamma$. We extend the framework considered so far to a three period $(t=0,1,2)$ model with stochastic shocks to the financiers' risk bearing capacity in the middle period. To keep the analysis streamlined, we take period 2 to be the "long run". Intuitively, period 2 will be a long-run steady state where countries have zero net foreign assets and run a zero trade balance. This allows us to quickly focus on the short-to-medium-run exchange rate dominated by financial forces and the long-run exchange rate completely anchored by fundamentals. We jump into the analysis here, and the original paper provides full details.

We assume that time-1 financial conditions, $\Gamma_{1}$, are stochastic. In the 3 -period economy with a long-run last period, the equilibrium exchange rates are:

$$
e_{0}=\frac{\Gamma_{0} \iota_{0}+\frac{R^{*}}{R} \mathbb{E}_{0}\left[\frac{\Gamma_{1} \iota_{1}+\iota_{2} R^{*} / R}{\Gamma_{1}+1}\right]}{\Gamma_{0}+1} ; \quad e_{1}=\frac{\Gamma_{1} \iota_{1}+\frac{R^{*}}{R} \mathbb{E}_{1}\left[\iota_{2}\right]}{\Gamma_{1}+1} ; \quad e_{2}=\iota_{2}
$$

Recall that the carry-trade return between period 0 and 1 is: $R^{c} \equiv \frac{R^{*}}{R} \frac{e_{1}}{e_{0}}-1$. Interestingly, in this case the carry trade also has "exposure to financial conditions". Notice that $\frac{\partial e_{1}}{\partial \Gamma_{1}}<0$ in the equations above, so that the Dollar (the funding currency) appreciates whenever there is a negative shock to the financiers' risk-bearing capacity $\left(\uparrow \Gamma_{1}, \downarrow e_{1}\right)$. Since in our chosen parametrization the carry trade is short Dollar and long Yen, we correspondingly have: $\frac{\partial R^{c}}{\partial \Gamma_{1}}<0$, the carry trade does badly whenever there is an ex-post negative shock to the financiers' risk-bearing capacity $\left(\uparrow \Gamma_{1}\right)$. Of course, that also means that expected carry trade returns between periods 1 and 2 are higher after the shock at time one takes place. 
The Fama Regression. The classic UIP regression of Fama (1984) is in this setting: is:

$$
\frac{e_{1}-e_{0}}{e_{0}}=\alpha+\beta_{\mathrm{UIP}}\left(R-R^{*}\right)+\varepsilon_{1}
$$

If UIP held, we would find $\beta_{\text {UIP }}=1$. However, a long empirical literature finds $\beta_{\mathrm{UIP}}<1$, and sometimes even $\beta_{\mathrm{UIP}}<0$. A $\beta_{\mathrm{UIP}}<1$ implies that exchange rates do not move enough on average to offset movements in the interest rate differential; a $\beta_{\text {UIP }}<0$ implies that exchange rate on average move as to add additional return beyond the interest rate differential. In the context of our simple 3-dates model, the coefficient of the Fama regression is given by:

$$
\beta_{\mathrm{UIP}}=\frac{1+\bar{\Gamma}_{1}-\Gamma_{0}}{\left(1+\Gamma_{0}\right)\left(1+\bar{\Gamma}_{1}\right)} .
$$

The presence of financial frictions $\Gamma_{0}>0$ is enough to generate $\beta_{\text {UIP }}<1$. To generate the more extreme result that $\beta_{\text {UIP }}<0$, we additionally require that $\bar{\Gamma}_{1}+1<\Gamma_{0}$, i.e. that risk bearing capacity is very low in period 0 compared to period $1 .{ }^{19}$ Intuitively, this suggests that, deep into a crisis, when current financial intermediation is extremely disrupted and forecasted to improve as one emerges from the crisis, expected currency returns have to be very high and this is achieved by capital gains on the currency in addition to the interest rate differential.

Hassan and Mano (2019) decompose the profitability of currency trading into a static carry trade component and a dynamic UIP component. Intuitively, Japan might have zero interest rates and New Zealand high interest rates, and this situation might persist for a number of years. The carry trade is about this persistent difference in interest rates. The UIP regression coefficient instead picks up variation over time around this "average" situation. They show empirically that most of the currency excess returns are due to the static component.

${ }^{19}$ Define the "certainty equivalent" $\bar{\Gamma}_{1}$ by $\frac{\bar{\Gamma}_{1}+R^{*} / R}{\bar{\Gamma}_{1}+1} \equiv \mathbb{E}_{0}\left[\frac{\Gamma_{1}+R^{*} / R}{\Gamma_{1}+1}\right]$. 


\subsection{Infinite Horizon, Monetary Policy, and Multiple Coun- tries}

Many extensions of the basic framework are possible. Some have been done, and others are still to be modeled. Extending the model to multiple periods is straightforward but also informative. An interesting force that emerges is myopia induced by the financial frictions. The exchange rate is the present value of future imbalances (trade and financial) and interest rate differentials, but the discount rate is increasing in the level of the frictions. When financial markets are very constrained, announcements about policy rates far into the future, like forward guidance or current news about future shocks, have lower effects on current exchange rates. It is illustrative to see this force at play even in the model with only two dates $t=0,1$ considered here. Recall, our most basic version of the model and the equilibrium exchange rate solution in equation (12), if we take the extreme limit of $\Gamma \uparrow \infty$, then we are in financial autarky and the exchange rate at both dates is pinned down only by contemporaneous fundamentals $e_{t}=\iota_{t}$. At the other extreme, if we take the limit of $\Gamma \downarrow 0$, then we are in a UIP world and the exchange rate is the "present value" of fundamentals in both periods $e_{0}=\frac{\iota_{0}+\mathbb{E}\left[\iota_{1}\right]}{2}$. The frictions modulate between forward looking and myopic solutions of the equilibrium exchange rate.

The model considered in this Chapter focuses on a simple real side of the economy, but allowing for a more developed monetary side is straightforward. ${ }^{20}$ Interesting open questions remain on the interaction between monetary policy, liquidity, and the level of the frictions. Ilzetzki, Jin et al. (2020b) study a model in which the frictions of the global financiers depend on the level of U.S. interest rates because the financiers' operations are financed with dollar liquidity. Mueller, Tahbaz-Salehi and Vedolin (2017) document empirically, and then link theoretically, monetary policy uncertainty to exchange rates via a segmented market model.

\footnotetext{
${ }^{20}$ Gabaix and Maggiori (2015) do so by introducing money in the utility function and then taking the cashless limit.
} 
An open research area is also the development of models with multiple (3 or more) countries that might be differentially affected (or in turn affect) the frictions of the global intermediation sector. The model presented so far focuses, like much of the international macro tradition, on a symmetric two country model for simplicity. However, the world is hardly symmetric, with some countries and assets playing special roles, a topic to which we turn next.

\subsection{Asymmetric Models: The Special Role of the US and US Dollar}

The global economy post World War II has been characterized by the hegemony of the US and its currency in many aspects of economic activity from asset markets to goods markets. In many important dimensions the US and the dollar are the exception rather than the rule when it comes to stylized facts of international macroeconomics. An interesting and growing literature, therefore, focuses on the role of the US and the dollar in the international monetary system.

This literature arises from important debates on the structure of the global monetary system. To mention some historical focal points: Keynes (1924) arguments against the return to the gold standard; Nurkse (1944) argument that multipolar systems tend to be unstable; Triffin (1961) positing of a fundamental dilemma between the amount of safe assets provided and the stability of the system; and Despres, Kindleberger and Salant (1966) counterpoint that the system is stable with a world banker at its center. Recently, the interest has been rekindled by Bernanke (2005) view that a global savings glut was responsible for low US rates and global imbalances. Much policy interest has also surrounded the growth of China as a global financial player that could in the future threaten US financial hegemony. ${ }^{21}$

The academic literature on these topics is vast, probably deserving of a handbook chapter on its own; here, we include only a brief overview since models that take global

\footnotetext{
${ }^{21}$ See for example Eichengreen, Mehl and Chitu (2019) and Farhi and Maggiori (2019).
} 
financial markets imperfection seriously have much to say on these topics. Caballero, Farhi and Gourinchas (2008) provide a framework to think about global imbalances and safe interest rates; one in which the country at the core of the system has an advantage in manufacturing saving instruments. One strand of the literature focused on asymmetric risk sharing to rationalize the external balance sheet of the US as a world banker and the resulting capital income despite a debtor position (Mendoza, Quadrini and Rios-Rull (2009); Gourinchas, Govillot and Rey (2011); Maggiori (2017)). Another strand focused on convenience yields to US treasuries and their implications for global imbalances (Jiang, Krishnamurthy and Lustig (2018, 2020a)).

A series of recent papers focused on self-fulfilling crises and multiple equilibria to understand global financial instability associated with high debt levels and are briefly reviewed below.

He, Krishnamurthy and Milbradt (2019) study the determinants of safe assets in a model with multiple countries. They focus on the interaction between debt levels, liquidity of the bonds, and demand for safe assets. In a world of high demand for safe assets, a country with a higher debt stock (even compared to GDP) can establish itself as the provider of safe assets because the debt is more liquid. Indeed, a larger debt market allows reserve managers to accumulate positions without fearing adverse price impact. If the demand for safe assets is low, however, a country with a high debt stock compared to GDP might struggle establishing itself as a safe asset provider because investors will focus on the roll-over risk that the high debt induces.

Farhi and Maggiori (2018) study the world supply and demand for reserve assets in a framework that trades off scarcity of the amount of safe assets and the stability of the system. Too few safe assets, then the system is stable but the scarcity can be recessionary. Too many safe assets, then the system might suffer a run. They show that a multipolar world, i.e. multiple countries providing safe assets, can be beneficial by expanding supply of safe assets but also lead to endogenous instability and reduce commitment by the issuers.

Gopinath and Stein (2020) and Chahrour and Valchev (2018) study the joint use 
of a currency to denominate financial assets and for transactions in the goods market. Gopinath and Stein (2020) stress the importance of dollar pricing in invoicing goods in international trade. Firms, especially emerging market firms, that price in dollars have a demand to accumulate assets in dollars to match the currency exposure; conversely, if firms have assets in dollars, they have incentives to also price the goods in dollars to match. Chahrour and Valchev (2018) focus on a medium of exchange, rather than unit of account, function of dollars in international trade, with also a complementarity to financial asset holdings.

\section{Conclusions}

In this chapter, we have reviewed recent advances in open economy analysis under segmented international markets. This type of analysis has recently boomed as a modeling tool to understand financial crises, the ensuing policy response (i.e., QE and FX intervention), deviations from arbitrage (CIP deviations), and, more generally, the impact of capital flows on exchange rates. It has also shed a different light on classic topics such as the exchange rate disconnect, the Backus and Smith risk-sharing condition, UIP failures, and the carry trade. Much remains to be done on the theoretical side, especially in quantifying the effects of market segmentation.

More importantly, the theoretical literature places global financial institutions and their risk taking at the core of international macroeconomics, making it imperative to have better measurement of these positions. Until recently, a detailed empirical analysis would have been unthinkable given severe data limitations. The last ten years or so, however, have witnessed an explosion of high-quality data on how financial institutions (and firms) allocate their capital globally. The improvement in data availability is in part the result of regulation imposed after the global financial crisis requiring private sector disclosures of risk taking. More generally, it arises from the intellectual realization that "who owns which assets" is an important question in macroeconomics, thus leading to better data collection in the private sector and by commercial data 
providers. One can have an informed hope that in a few years the next version of the Handbook of International Economics will include a chapter on the scientific advances that will come from this empirical effort.

\section{References}

Adrian, Tobias and Hyun Song Shin, "Procyclical Leverage and Value-at-Risk," The Review of Financial Studies, 2014, 27 (2), 373-403.

Adrian, Tobias, Erkko Etula, and Hyun Song Shin, "Risk Appetite and Exchange Rates," Federal Reserve Bank of New York Staff Report, 2014.

Adrian, Tobias, Erkko Etula, and Jan JJ Groen, "Financial Amplification of Foreign Exchange Risk Rremia," European Economic Review, 2011, 55 (3), 354-370.

Allen, Polly R. and Peter B. Kenen, Asset Markets and Exchange Rates: Modeling an Open Economy, Cambridge University Press, Cambridge, UK, 1983.

Alvarez, Fernando, Andrew Atkeson, and Patrick J Kehoe, "Money, Interest Rates, and Exchange Rates with Endogenously Segmented Markets," Journal of political economy, 2002, 110 (1), 73-112.

Alvarez, Fernando, Andrew Atkeson, and Patrick J Kehoe, "Time-Varying Risk, Interest Rates, and Exchange Rates in General Equilibrium," Review of Economic Studies, 2009, 76 (3), 851-878.

Amador, Manuel, Javier Bianchi, Luigi Bocola, and Fabrizio Perri, "Exchange Rate Policies at the Zero Lower Bound," The Review of Economic Studies, 2020, 87 (4), 1605-1645.

Avdjiev, Stefan, Wenxin Du, Catherine Koch, and Hyun Song Shin, "The dollar, bank leverage, and deviations from covered interest parity," American Economic Review: Insights, 2019, 1 (2), 193-208.

Bacchetta, Philippe and Eric Van Wincoop, "Infrequent Portfolio Decisions: A Solution to the Forward Discount Puzzle," American Economic Review, 2010, 100 (3), 870-904.

Bacchetta, Philippe, Eric van Wincoop, and Eric R Young, "Infrequent Random Portfolio Decisions in an Open Economy Model," Technical Report 2020. 
Bacchetta, Philippe, Simon Tieche, and Eric van Wincoop, "International Portfolio Choice with Frictions: Evidence from Mutual Funds," 2020.

Backus, David K. and Gregor W. Smith, "Consumption and Real Exchange Rates in Dynamic Economies with Non-Traded Goods," Journal of International Economics, 1993, 35 (3-4), 297-316.

Backus, David K. and Patrick J. Kehoe, "On the Denomination of Government Debt: A Critique of the Portfolio Balance Approach," Journal of Monetary Economics, May 1989, 23 (3), 359-376.

Backus, David K., Patrick J. Kehoe, and Finn E. Kydland, "International Real Business Cycles," Journal of Political Economy, August 1992, 100 (4), 745-75.

Basu, Suman Sambha, Emine Boz, Gita Gopinath, Francisco Roch, and Filiz Unsal, "A Conceptual Model for the Integrated Policy Framework," 2020.

Bernanke, Ben, "The Global Saving Glut and the U.S. Current Account Deficit," Sandridge Lecture, 2005.

Bianchi, Javier, "Credit Externalities: Macroeconomic Effects and Policy Implications," American Economic Review, 2010, 100 (2), 398-402.

Bianchi, Javier and Guido Lorenzoni, "Optimal Policy in Open Economy," Chapter in Handbook of International Economics, 2021.

Blanchard, Olivier, Francesco Giavazzi, and Filipa Sa, "The U.S. Current Account and the Dollar," Technical Report, National Bureau of Economic Research 2005 .

Blanchard, Olivier, Irineu de Carvalho Filho, and Gustavo Adler, "Can Sterilized Foreign Exchange Intervention Stem Exchange Rate Pressures from the Global Financial Cycle?," Unpublished Manuscript, April 2014.

Branson, William H. and Dale W. Henderson, "The Specification and Influence of Asset Markets," in R. W. Jones and P. B. Kenen, eds., Handbook of International Economics, Vol. 2 of Handbook of International Economics, Elsevier, 00 1985, chapter 15, pp. 749-805.

Branson, William H., Hannu Halttunen, and Paul Masson, "Exchange Rates in the Short Run: Some Further Results," European Economic Review, October 1979, 12 (4), 395-402. 
Broner, Fernando, Alberto Martin, Lorenzo Pandolfi, and Tomas Williams, "Winners and Losers from Sovereign Debt Inflows," NBER Working Paper, 2020, (w27772).

Brunnermeier, Markus K and Yuliy Sannikov, "International Credit Flows and Pecuniary Externalities," American Economic Journal: Macroeconomics, 2015, 7 (1), 297-338.

Brunnermeier, Markus K., Stefan Nagel, and Lasse H. Pedersen, "Carry Trades and Currency Crashes," in "NBER Macroeconomics Annual 2008, Volume 23" NBER Chapters, NBER, Inc, 2009, pp. 313-347.

Burstein, Ariel and Gita Gopinath, "Chapter 7 - International Prices and Exchange Rates," in Kenneth Rogoff Elhanan Helpman and Gita Gopinath, eds., Handbook of International Economics, Vol. 4 of Handbook of International Economics, Elsevier, 2015, pp. $391-451$.

Caballero, Ricardo J and Alp Simsek, "A Model of Fickle Capital Flows and Retrenchment," Journal of Political Economy, 2020, 128 (6), 2288-2328.

Caballero, Ricardo J. and Arvind Krishnamurthy, "International and Domestic Collateral Constraints in a Model of Emerging Market Crises," Journal of Monetary Economics, 2001, 48 (3), 513-548.

Caballero, Ricardo J, Emmanuel Farhi, and Pierre-Olivier Gourinchas, "An Equilibrium Model of "Global Imbalances" and Low Interest Rates," American Economic Review, 2008, 98 (1), 358-393.

Calvo, Guillermo A and Carlos Alfredo Rodriguez, "A Model of Exchange Rate Determination Under Currency Substitution and Rational Expectations," The Journal of Political Economy, 1977, pp. 617-625.

Camanho, Nelson, Harald Hau, and Hélène Rey, "Global Portfolio Rebalancing and Exchange Rates," Technical Report, National Bureau of Economic Research 2018.

Cavallino, Paolo, "Capital Flows and Foreign Exchange Intervention," American Economic Journal: Macroeconomics, 2019, 11 (2), 127-70.

Cenedese, Gino, Pasquale Della Corte, and Tianyu Wang, "Currency Mispricing and Dealer Balance Sheets," 2020.

Chahrour, Ryan and Rosen Valchev, "International Medium of Exchange: Privilege and Duty," Working Paper, 2018. 
Chari, Varadarajan V, Patrick J Kehoe, and Ellen R McGrattan, "Can Sticky Price Models Generate Volatile and Persistent Real Exchange Rates?," The Review of Economic Studies, 2002, 69 (3), 533-563.

Chinn, Menzie D and Guy Meredith, "Monetary Policy and Long-Horizon Uncovered Interest Parity," IMF staff papers, 2004, 51 (3), 409-430.

Colacito, Riccardo and Mariano M. Croce, "Risks for the Long Run and the Real Exchange Rate," Journal of Political Economy, 2011, 119 (1), 153-181.

Cole, Harold L. and Maurice Obstfeld, "Commodity Trade and International Risk Sharing : How Much Do Financial Markets Matter?," Journal of Monetary Economics, 1991, 28 (1), 3-24.

Coppola, Antonio, Matteo Maggiori, Brent Neiman, and Jesse Schreger, "Redrawing the Map of Global Capital Flows: The Role of Cross-Border Financing and Tax Havens," Technical Report, National Bureau of Economic Research 2020.

Corsetti, Giancarlo, Luca Dedola, and Sylvain Leduc, "International Risk Sharing and the Transmission of Productivity Shocks," The Review of Economic Studies, 2008, 75 (2), 443-473.

Corte, Pasquale Della, Steven J Riddiough, and Lucio Sarno, "Currency Premia and Global Imbalances," The Review of Financial Studies, 2016, 29 (8), 2161-2193.

Dávila, Eduardo and Anton Korinek, "Pecuniary Externalities in Economies with Financial Frictions," The Review of Economic Studies, 2017, 85 (1), 352-395.

Davis, Scott, Michael B Devereux, and Changhua Yu, "Sudden Stops and Optimal Foreign Exchange Intervention," NBER Working Paper, 2020, (w28079).

De Grauwe, Paul, "The Exchange Rate in a Portfolio Balance Model with a Banking Sector," Journal of International Money and Finance, January 1982, 1 (1), 225-239.

De Long, J. Bradford, Andrei Shleifer, Lawrence H. Summers, and Robert J. Waldmann, "Noise Trader Risk in Financial Markets," Journal of Political Economy, 1990, pp. 703-738.

De Long, J. Bradford, Andrei Shleifer, Lawrence H. Summers, and Robert J. Waldmann, "Positive Feedback Investment Strategies and Destabilizing Rational Speculation," Journal of Finance, 1990, 45 (2), 379-395. 
de Macedo, Jorge Braga and Urho Lempinen, "Exchange Rate Dynamics Revisited," NBER Working Papers 19718, National Bureau of Economic Research, Inc December 2013.

Despres, Emile, Charles P. Kindleberger, and Walter S. Salant, The Dollar and World Liquidity: A Minority View., Brookings Institution, 1966.

Devereux, Michael B. and Charles Engel, "Monetary Policy in the Open Economy Revisited: Price Setting and Exchange-Rate Flexibility," Review of Economic Studies, 2003, 70 (4), 765-783.

Diebold, Francis X. and Peter Pauly, "Endogenous Risk in a Portfolio-Balance Rational-Expectations Model of the Deutschemark-Dollar Rate," European Economic Review, January 1988, 32 (1), 27-53.

Dominguez, Kathryn M and Jeffrey A Frankel, "Does Foreign-Exchange Intervention Matter? The Portfolio Effect," American Economic Review, December 1993, 83 (5), 1356-69.

Dominguez, Kathryn M. and Jeffrey A. Frankel, Does Foreign Exchange Intervention Work?, Institute for International Economics, 1993.

Dornbusch, Rudiger, "Expectations and Exchange Rate Dynamics," Journal of Political Economy, 1976, 84 (6), 1161.

Dornbusch, Rudiger and Stanley Fischer, "Exchange Rates and the Current Account," American Economic Review, December 1980, 70 (5), 960-71.

Driskill, Robert and Stephen McCafferty, "Exchange-Rate Variability, Real and Monetary Shocks, and the Degree of Capital Mobility Under Rational Expectations," Quarterly Journal of Economics, 1980, 95 (3), 577-586.

Driskill, Robert and Stephen McCafferty, "Speculation, Rational Expectations, and Stability of the Foreign Exchange Market," Journal of International Economics, February 1980, 10 (1), 91-102.

Du, Wenxin, Alexander Tepper, and Adrien Verdelhan, "Deviations from covered interest rate parity," The Journal of Finance, 2018, 73 (3), 915-957.

Du, Wenxin and Jesse Schreger, "CIP Deviations, the Dollar, and Frictions in International Capital Markets," Chapter in Handbook of International Economics, 2021. 
Du, Wenxin, Benjamin M Hébert, and Amy Wang Huber, "Are Intermediary Constraints Priced?," Technical Report, National Bureau of Economic Research 2019 .

Dumas, Bernard, "Dynamic Equilibrium and the Real Exchange Rate in a Spatially Separated World," Review of Financial Studies, 1992, 5 (2), 153-80.

Eichengreen, Barry, Arnaud Mehl, and Livia Chitu, How global currencies work: past, present, and future, Princeton University Press, 2019.

Engel, Charles and Steve Pak Yeung Wu, "Liquidity and Exchange Rates: An Empirical Investigation," Technical Report, National Bureau of Economic Research 2018.

Evans, Martin and Richard K. Lyons, "Order Flow and Exchange Rate Dynamics," Journal of Political Economy, 2002, 110 (1), 170-180.

Fama, Eugene F., "Forward and Spot Exchange Rates," Journal of Monetary Economics, 1984, 14 (3), 319-338.

Fanelli, Sebastian and Ludwig Straub, "A Theory of Foreign Exchange Interventions," NBER Working Paper, 2020, (w27872).

Fang, Xiang and Yang Liu, "Volatility, Intermediaries, and Exchange Rates.," Journal of Financial Economics, 2021.

Farhi, Emmanuel and Matteo Maggiori, "A Model of the International Monetary System," The Quarterly Journal of Economics, 2018, 133 (1), 295-355.

Farhi, Emmanuel and Matteo Maggiori, "China versus the United States: IMS meets IPS," in "AEA Papers and Proceedings," Vol. 109 2019, pp. 476-81.

Farhi, Emmanuel and Xavier Gabaix, "Rare Disasters and Exchange Rates," The Quarterly Journal of Economics, 2016, 131 (1), 1-52.

Forbes Magazine, http://www.forbes.com/sites/afontevecchia/2011/04/ 18/mantega-inflation-under-control-in-brazil-as-qe2-pressures-real/ 2011.

Fratzscher, Marcel, Lukas Menkhoff, Lucio Sarno, Maik Schmeling, and Tobias Stoehr, "Systematic Intervention and Currency Risk Premia," Available at SSRN 311990\%, 2019. 
Fratzscher, Marcel, Oliver Gloede, Lukas Menkhoff, Lucio Sarno, and Tobias Stöhr, "When is Foreign Exchange Intervention Effective? Evidence from 33 Countries," American Economic Journal: Macroeconomics, 2019, 11 (1), 132-56.

Froot, Kenneth A. and Tarun Ramadorai, "Currency Returns, Intrinsic Value, and Institutional-Investor Flows," Journal of Finance, 2005, 60 (3), 1535-1566.

Gabaix, Xavier and Matteo Maggiori, "International Liquidity and Exchange Rate Dynamics," Quarterly Journal of Economics, 2015, 3, 1369-1420.

Garleanu, Nicolae and Lasse Heje Pedersen, "Margin-Based Asset Pricing and Deviations from the Law of One Price," Review of Financial Studies, 2011, 24 (6), 1980-2022.

Gopinath, Gita and Jeremy C Stein, "Banking, Trade, and the Making of a Dominant Currency," The Quarterly Journal of Economics, 102020.

Gourinchas, Pierre-Olivier, Nicolas Govillot, and Hélène Rey, "Exorbitant Privilege and Exorbitant Duty," Working paper, UC Berkeley and LBS, 2011.

Gourinchas, Pierre-Olivier, Walker Ray, and Dimitri Vayanos, "A PreferredHabitat Model of Term Premia and Currency Risk," mimeo, 2020.

Greenwood, Robin M, Samuel Gregory Hanson, Jeremy C Stein, and Aditya Sunderam, "A Quantity-Driven Theory of Term Premia and Exchange Rates," NBER Working Paper, 2020, (w27615).

Gromb, Denis and Dimitri Vayanos, "Equilibrium and Welfare in Markets with Financially Constrained Arbitrageurs," Journal of Financial Economics, 2002, 66 (2), 361-407.

Hassan, Tarek A., "Country Size, Currency Unions, and International Asset Returns," Journal of Finance, 2013, 68 (6), 2269-2308.

Hassan, Tarek A and Rui C Mano, "Forward and spot exchange rates in a multicurrency world," The Quarterly Journal of Economics, 2019, 134 (1), 397-450.

Hassan, Tarek A, Thomas M Mertens, and Tony Zhang, "A Risk-Based Theory of Exchange Rate Stabilization," 2020.

Hau, Harald and Hélène Rey, "Exchange Rates, Equity Prices, and Capital Flows," Review of Financial Studies, 2006, 19 (1), 273-317. 
Hau, Harald, Massimo Massa, and Joel Peress, "Do Demand Curves for Currencies Slope Down? Evidence from the MSCI Global Index Change," Review of Financial Studies, April 2010, 23 (4), 1681-1717.

He, Zhiguo, Arvind Krishnamurthy, and Konstantin Milbradt, "A Model of Safe Asset Determination," American Economic Review, 2019, 109 (4), 1230-62.

Henderson, Dale W. and Kenneth Rogoff, "Negative Net Foreign Asset Positions and Stability in a World Portfolio Balance Model," Journal of International Economics, August 1982, 13 (1-2), 85-104.

Hong, Harrison and Motohiro Yogo, "What Does Futures Market Interest Tell Us about the Macroeconomy and Asset Prices?," Journal of Financial Economics, 2012, 105 (3), 473-490.

House, Chris, Christian Proebsting, and Linda Tesar, "Czeching out the Effects of an Exchange Rate Intervention," Working Paper, 2021.

Ilzetzki, Ethan, Carmen M Reinhart, and Kenneth S Rogoff, "Will the Secular Decline In Exchange Rate and Inflation Volatility Survive COVID-19?," Technical Report, National Bureau of Economic Research 2020.

Ilzetzki, Ethan, Keyu Jin et al., "The Puzzling Change in the International Transmission of US Macroeconomic Policy Shocks," NBER Chapters, 2020.

Itskhoki, Oleg and Dmitry Mukhin, "Mussa Puzzle Redux," Available at SSRN 3423438, 2020.

Itskhoki, Oleg and Dmitry Mukhin, "Exchange Rate Disconnect in General Equilibrium," Forthcoming in Journal of Political Economy, 2021.

Jeanne, Olivier and Andrew K. Rose, "Noise Trading and Exchange Rate Regimes," Quarterly Journal of Economics, 2002, 117 (2), 537-569.

Jiang, Zhengyang, Arvind Krishnamurthy, and Hanno Lustig, "Foreign Safe Asset Demand and the Dollar Exchange Rate," NBER Working Paper, 2018, (w24439).

Jiang, Zhengyang, Arvind Krishnamurthy, and Hanno Lustig, "Dollar Safety and the Global Financial Cycle," NBER Working Paper, 2020, (w27682).

Jiang, Zhengyang, Robert Richmond, and Tony Zhang, "A Portfolio Approach to Global Imbalances," Available at SSRN, 2020. 
Jordan, Thomas J., "Small Country — Big Challenges; Switzerland's Monetary Policy Response to the Coronavirus Pandemic," Speech for the 2020 IMF Michel Camdessus Central Banking Lecture, 2020.

Keynes, John Maynard, A Tract on Monetary Reform, Macmillan and Co., London, 1924.

Kim, Young Ju, Zhipeng Liao, and Aaron Tornell, "Speculators Positions and Exchange Rate Forecasts: Beating Random Walk Models," Unpublished Manuscript UCLA, 2014.

Koijen, Ralph SJ and Motohiro Yogo, "Exchange Rates and Asset Prices in a Global Demand System," Technical Report, National Bureau of Economic Research 2020 .

Kouri, Pentti J. K., "The Exchange Rate and the Balance of Payments in the Short Run and in the Long Run: A Monetary Approach," Scandinavian Journal of Economics, 1976, 78 (2), 280-304.

Lettau, Martin, Matteo Maggiori, and Michael Weber, "Conditional Risk Premia in Currency Markets and Other Asset Classes," Journal of Financial Economics, $2014,114(2), 197-225$.

Levinson, Charles, "Interview Transcript: Stanley Fischer," Wall Street Journal. http://online.wsj.com/news/articles/ SB10001424052702304510704575562410676436730 (accessed January 15, 2014) 2010.

Lilley, Andrew and Gianluca Rinaldi, "Currency betas and interest rate spreads," Working paper, 2020.

Lilley, Andrew, Matteo Maggiori, Brent Neiman, and Jesse Schreger, "Exchange Rate Reconnect," Forthcoming in Review of Economics and Statistics, 2020, pp. $1-28$.

Lucas, Robert E., "Interest Rates and Currency Prices in a Two-Country World," Journal of Monetary Economics, 1982, 10 (3), 335-359.

Lustig, Hanno and Adrien Verdelhan, "Does Incomplete Spanning in International Financial Markets Help to Explain Exchange Rates?," American Economic Review, 2019, 109 (6), 2208-44. 
Lustig, Hanno, Andreas Stathopoulos, and Adrien Verdelhan, "The Term Structure of Currency Carry Trade Tisk Premia," American Economic Review, 2019, 109 (12), 4142-77.

Lustig, Hanno, Nikolai Roussanov, and Adrien Verdelhan, "Common Risk Factors in Currency Markets," Review of Financial Studies, 2011, 24 (11), 37313777 .

Maggiori, Matteo, "Financial Intermediation, International Risk Sharing, and Reserve Currencies," American Economic Review, 2017, 107 (10), 3038-3071.

Maggiori, Matteo, Brent Neiman, and Jesse Schreger, "The rise of the dollar and fall of the Euro as international currencies," AEA Papers and Proceedings, 2019, $109,521-26$.

Maggiori, Matteo, Brent Neiman, and Jesse Schreger, "International Currencies and Capital Allocation," Journal of Political Economy, 2020, 128 (6), 2019-2066.

Meese, Richard A. and Kenneth Rogoff, "Empirical Exchange Rate Models of the Seventies: Do they Fit Out of Sample?," Journal of International Economics, February 1983, 14 (1-2), 3-24.

Mendoza, Enrique G., "Sudden Stops, Financial Crises, and Leverage," American Economic Review, 2010, 100 (5), 1941-1966.

Mendoza, Enrique G, Vincenzo Quadrini, and Jose-Victor Rios-Rull, "Financial Integration, Financial Development, and Global Imbalances," Journal of Political Economy, 2009, 117 (3).

Menkhoff, Lukas, Lucio Sarno, Maik Schmeling, and Andreas Schrimpf, "Carry Trades and Global Foreign Exchange Volatility," The Journal of Finance, 2012, 67 (2), 681-718.

Morelli, Juan M, Pablo Ottonello, and Diego J Perez, "Global Banks and Systemic Debt Crises," New York University and University of Michigan, 2019.

Mueller, Philippe, Alireza Tahbaz-Salehi, and Andrea Vedolin, "Exchange Rates and Monetary Policy Uncertainty," The Journal of Finance, 2017, 72 (3), $1213-1252$.

Mussa, Michael, "Nominal Exchange Rate Regimes and the Behavior of Real Exchange Rates: Evidence and Implications," Carnegie-Rochester Conference Series on Public Policy, 1986, 25, 117-214. 
Nurkse, Ragnar, International Currency Experience: Lessons of the Interwar Period number 4, League of Nations, 1944.

Obstfeld, Maurice, "External Adjustment," Review of World Economics, 2004, 140 (4), 541-568.

Obstfeld, Maurice and Kenneth Rogoff, "Exchange Rate Dynamics Redux," Journal of Political Economy, 1995, 103 (3), 624-660.

Obstfeld, Maurice and Kenneth Rogoff, "The Six Major Puzzles in International Macroeconomics: Is There a Common Cause?," in Ben S. Bernanke and Kenneth Rogoff, eds., NBER Macroeconomics Annual 2000, Volume 15, The MIT Press, 2001, pp. 339-412.

Pandolfi, Lorenzo and Tomas Williams, "Capital Flows and Sovereign Debt Markets: Evidence from Index Rebalancings," Journal of Financial Economics, 2019, $132(2), 384-403$.

Pavlova, Anna and Roberto Rigobon, "Asset Prices and Exchange Rates," Review of Financial Studies, 2007, 20, 1139-1180.

Pavlova, Anna and Roberto Rigobon, "The Role of Portfolio Constraints in the International Propagation of Shocks," Review of Economic Studies, October 2008, 75 (4), 1215-1256.

Pavlova, Anna and Roberto Rigobon, "An Asset-Pricing View of External Adjustment," Journal of International Economics, 2010, 80 (1), 144-156.

Pavlova, Anna and Roberto Rigobon, "Equilibrium Portfolios and External Adjustment Under Incomplete Markets," Unpublished Manuscript LBS, 2012.

Pellegrino, Bruno, Enrico Spolaore, and Romain T Wacziarg, "Barriers to Global Capital Allocation," Available at SSRN 3752485, 2020.

Richmond, Robert J, "Trade Network Centrality and Currency Risk Premia," The Journal of Finance, 2019, 74 (3), 1315-1361.

Sarno, Lucio and Mark P. Taylor, "Official Intervention in the Foreign Exchange Market: Is It Effective and, If so, How Does It Work?," Journal of Economic Literature, 2001, 39 (3), pp. 839-868.

Schmitt-Grohé, Stephanie and Martın Uribe, "Closing small open economy models," Journal of international Economics, 2003, 61 (1), 163-185. 
Schmitt-Grohé, Stephanie and Martin Uribe, "Downward nominal wage rigidity, currency pegs, and involuntary unemployment," Journal of Political Economy, 2016, 124 (5), 1466-1514.

Shleifer, Andrei and Robert W. Vishny, "The Limits of Arbitrage," Journal of Finance, 1997, 52 (1), 35-55.

Sialm, Clemens and Qifei Zhu, "Currency Management by International Fixed Income Mutual Funds," Available at SSRN, 2020.

Tobin, James and Jorge B. de Macedo, "The Short-Run Macroeconomics of Floating Exchange Rates: An Exposition," Cowles Foundation Discussion Papers 522, Cowles Foundation for Research in Economics, Yale University 1979.

Triffin, Robert, Gold and the Dollar Crisis: The Future of Convertibility, New Haven, Yale University Press, Connecticut, 1961.

Vayanos, Dimitri and Jean-Luc Vila, "A Preferred-Habitat Model of the Term Structure of Interest Rates," Econometrica, 2020.

Verdelhan, Adrien, "A Habit-Based Explanation of the Exchange Rate Risk Premium," Journal of Finance, 2010, 65 (1), 123-146.

Verdelhan, Adrien, "The Share of Systematic Variation in Bilateral Exchange Rates," The Journal of Finance, 2018, 73 (1), 375-418. 